\title{
Passive Sampling in Regulatory Chemical Monitoring of Nonpolar Organic Compounds in the Aquatic Environment
}

Kees Booij, ${ }^{*, a}$ Craig D. Robinson, ${ }^{b}$ Robert M. Burgess, ${ }^{c}$ Philipp Mayer, ${ }^{d}$ Cindy A. Roberts, ${ }^{e}$ Lutz Ahrens, ${ }^{f}$ Ian J. Allan, ${ }^{g}$ Jan Brant, ${ }^{\text {h }}$ Lisa Jones, ${ }^{i}$ Uta R. Kraus, ${ }^{j}$ Martin M. Larsen, ${ }^{k}$ Peter Lepom, ${ }^{1}$ Jördis Petersen, ${ }^{\mathrm{m}}$ Daniel Pröfrock, ${ }^{\mathrm{m}}$ Patrick Roose, ${ }^{\mathrm{n}}$ Sabine Schäfer, ${ }^{\mathrm{o}}$ Foppe Smedes, ${ }^{\mathrm{p}, \mathrm{q}}$ Céline Tixier, ${ }^{\mathrm{r}}$ Katrin Vorkamp, ${ }^{\mathrm{s}}$ and Paul Whitehouse ${ }^{t}$

${ }^{a}$ NIOZ Royal Netherlands Institute for Sea Research, PO Box 59, 1790 AB Texel, The Netherlands

bMarine Scotland Science, Marine Laboratory, 375 Victoria Road, Aberdeen AB30 1AD, U.K.

${ }^{c}$ U.S. Environmental Protection Agency, Office of Research and Development, National Health and Environmental Effects Research Laboratory, Atlantic Ecology Division, 27 Tarzwell Drive, Narragansett, Rhode Island 02882, United States

${ }^{\mathrm{d}}$ Department of Environmental Engineering, Technical University of Denmark, Anker Engelunds Vej 1, DK-2800 Kongens Lyngby, Denmark

${ }^{\mathrm{e}}$ U.S. Environmental Protection Agency, Office of Research and Development, 1200 Pennsylvania Avenue, Washington, D.C. 20460, United States

${ }^{f}$ Department of Aquatic Sciences and Assessment, Swedish University of Agricultural Sciences (SLU), Box 7050, SE-750 07 Uppsala, Sweden

${ }^{\mathrm{g}}$ Norwegian Institute for Water Research (NIVA), Gaustadalleen 21, NO-0349 Oslo, Norway

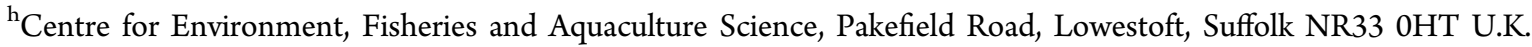

${ }^{\mathrm{i}}$ Dublin City University, Glasnevin, Dublin, Ireland

${ }^{\mathrm{j}}$ Federal Maritime and Hydrographic Agency, Wuestland 2, 22589 Hamburg, Germany

${ }^{\mathrm{k}}$ Aarhus University, Department of Bioscience, Frederiksborgvej 399, 4000 Roskilde, Denmark

${ }^{1}$ Federal Environment Agency, Laboratory for Water Analysis, Bismarckplatz 1, 14193 Berlin, Germany

${ }^{\mathrm{m}}$ Helmholtz-Zentrum Geesthacht, Institute of Coastal Research, Department Marine Bioanalytical Chemistry, Max-Planck Strasse 1, 21502 Geesthacht, Germany

${ }^{\mathrm{n}}$ Royal Belgian Institute of Natural Sciences, Operational Directorate Natural Environment, Gulledelle 100, B-1200 Brussels, Belgium

${ }^{\circ}$ Federal Institute of Hydrology, Am Mainzer Tor 1, 56068 Koblenz, Germany

${ }^{\mathrm{P}}$ Masaryk University, RECETOX, Kamenice 753/5, 62500 Brno, Czech Republic

${ }^{\mathrm{q}}$ Deltares, P.O. Box 85467, 3508 AL Utrecht, The Netherlands

${ }^{\mathrm{r}}$ Ifremer, Unit of Biogeochemistry and Ecotoxicology, Lab. Biogeochemistry of Organic Contaminants, BP 21105, 44311 Nantes Cedex 3, France

${ }^{s}$ Aarhus University, Department of Environmental Science, Frederiksborgvej 399, 4000 Roskilde, Denmark

${ }^{t}$ Environment Agency, Evidence Directorate, Red Kite House, Howbery Park OX10 8BD, United Kingdom

Supporting Information 
ABSTRACT: We reviewed compliance monitoring requirements in the European Union, the United States, and the Oslo-Paris Convention for the protection of the marine environment of the North-East Atlantic, and evaluated if these are met by passive sampling methods for nonpolar compounds. The strengths and shortcomings of passive sampling are assessed for water, sediments, and biota. Passive water sampling is a suitable technique for measuring concentrations of freely dissolved compounds. This method yields results that are incompatible with the EU's quality standard definition in terms of total concentrations in water, but this definition has little scientific basis. Insufficient quality control is a present weakness of passive sampling in water. Laboratory performance studies and the development of standardized methods are needed to improve data quality and to encourage the use of passive sampling by commercial laboratories and monitoring agencies. Successful prediction of bioaccumulation based on passive sampling is

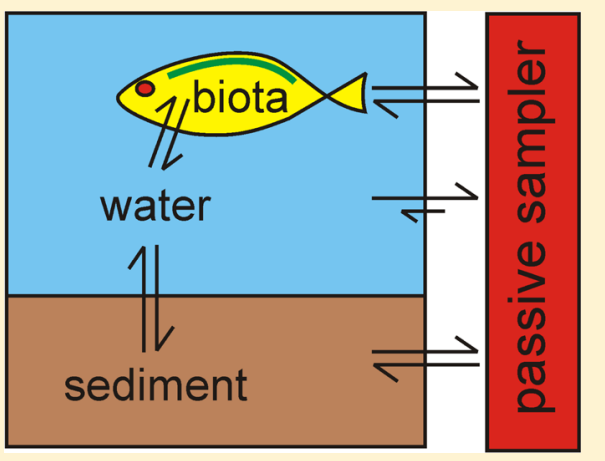
well documented for organisms at the lower trophic levels, but requires more research for higher levels. Despite the existence of several knowledge gaps, passive sampling presently is the best available technology for chemical monitoring of nonpolar organic compounds. Key issues to be addressed by scientists and environmental managers are outlined.

\section{INTRODUCTION}

Great progress has been made over the past few decades in the field of passive sampling of nonpolar organic compounds (log octanol-water partition coefficients $\left.\left(\log K_{\mathrm{ow}}\right)>4\right)$ in the aquatic environment. With such methods, a sorption phase is exposed in a medium (e.g., water, sediment), where it samples the target compounds at a rate that is proportional to the difference in chemical activity between sampler and medium, and where the uptake kinetics are controlled by passive processes (diffusion and ambient convection), until equilibrium is attained. By contrast, grab sampling methods aim to quantitatively extract compounds from a distinct water volume (e.g., solid phase extraction, liquidliquid extraction). Passive sampling allows measurement of the concentrations of freely dissolved compounds $\left(C_{\text {free }}\right)$, while grab sampling yields total dissolved concentrations (freely dissolved + colloidally bound) or total concentrations (total dissolved + particulate).

Various passive sampler designs have been proposed for nonpolar organic compounds since the early 1980s (Supporting Information, Table S1), ${ }^{1-7}$ of which solid phase microextraction $(\mathrm{SPME})^{8}$ and semipermeable membrane devices (SPMDs) ${ }^{9}$ were the first designs that were used on a wider scale by multiple research and monitoring groups. Passive sampling devices (PSDs) can be broadly categorized as single-phase samplers, which only consist of a single polymer (e.g., low-density polyethylene) and dual-phase samplers, which consist of a sorption phase that is enclosed by a polymeric membrane (e.g., SPMDs, nonpolar version of the Chemcatcher).

The recognition of the added value of passive sampling by regulators is rather limited. PSDs are considered by European Union (EU) regulators to be useful but complementary tools for assessing environmental contamination under the EU Water Framework Directive. ${ }^{10}$ The recent European Chemical Agency workshop on contaminated sediment risk assessments noted the utility of passive sampling for performing these assessments. ${ }^{11}$ Environmental authorities in the U.S. actively support the use of passive sampling in environmental assessments. ${ }^{12-15}$ For example, the U.S. Environmental Protection Agency's (U.S. EPA) Superfund program for the remediation of contaminated sites has encouraged the application of passive sampling at their sites around the country. ${ }^{14}$ The Oslo-Paris Convention for the protection of the marine environment of the North-East Atlantic (OSPAR) recognizes the potential of passive sampling for the risk assessment of nonpolar compounds in sediments and water, based on a trial survey in the OSPAR area. ${ }^{16-18}$

In January 2013, the International Council for the Exploration of the Sea (ICES) organized a workshop that aimed to 1. review the state of the knowledge on the applicability of passive sampling in relation to compliance monitoring, 2. review the links between passive sampling and chemical monitoring in biota, and 3. identify the research needs to further apply passive sampling in marine monitoring assessments. ${ }^{19}$ The present review builds upon the findings of this workshop with respect to the monitoring of nonpolar compounds in water, sediment, and biota, considering that passive sampling of metals, polar organic compounds, and volatile molecules require separate evaluation. The United States perspective and experience with passive sampling in environmental monitoring was included in what started as primarily a European exercise in order to provide greater scientific and regulatory robustness to this review's analysis. In addition, inclusion of both the European and United States approaches provides interesting opportunities for contrasting the ways in which two of the largest political entities have applied passive sampling toward a specific aspect of environmental regulation. The aim of this review was 1 . to evaluate the differences in perspective between environmental managers and passive sampling scientists with respect to the risk assessment of nonpolar compounds in the aquatic environment, and 2. to critically address the achievements and shortcomings of passive sampling research in relation to the needs of environmental managers, based on documented evidence.

\section{REQUIREMENTS OF COMPLIANCE MONITORING}

A major focus of chemical monitoring in the aquatic environment is to assess compliance with water quality thresholds that aim to protect aquatic organisms and humans from the adverse effects of chemicals. ${ }^{20,21}$ Additional purposes are the assessment of the effectiveness of emission control policies (temporal trends) and source identification (geographical trends). The general approach is to set concentration thresholds in environmental matrices that offer adequate protection, and to set performance requirements for the methods that are used to measure actual concentrations in the environment.

The basis for monitoring programs can be national legislation (e.g., U.S. Clean Water Act), supra-national legislation (e.g., EU Water Framework Directive, WFD), or international treaties (e.g., regional seas conventions, such as OSPAR, and the 
Canadian and United States International Joint Commission for the protection of transboundary waters). In this review, we take chemical monitoring in the U.S., EU, and the North-East Atlantic as examples to discuss the performance of passive sampling for demonstrating compliance with legally defined concentration thresholds. We selected these three regions because the status of chemical monitoring is sufficiently similar to identify general requirements, yet sufficiently different to illustrate that various approaches toward compliance monitoring are possible.

Concentration Thresholds. Compliance monitoring of European inland surface waters, estuaries, groundwater, coastal waters, and territorial waters is regulated by the WFD, ${ }^{22}$ the directive on Environmental Quality Standards (EQSs), ${ }^{23}$ and the directive on Technical Specifications for Chemical Analysis and Monitoring of Water Status. ${ }^{24}$ Alongside these legally binding directives, technical guidance documents have been published for the implementation of the WFD. These documents provide guidance for defining quality standards (QS) for the protection of freshwater and saltwater pelagic and benthic communities, top predators, and humans, proposing to adopt the most protective QS as overall EQS. ${ }^{20}$ To compare biota QSs ( $\mu \mathrm{g} \mathrm{kg}^{-1}$ wet weight) with those derived for the protection of pelagic communities $\left(\mu \mathrm{g} \mathrm{L}^{-1}\right)$ the former have to be converted to equivalent water concentrations using appropriate bioaccumulation factors (BAFs).

For nonpolar organic compounds, the EQS guidance document states that laboratory toxicity and bioconcentration tests usually contain low levels of total organic carbon (TOC) in the test system, and that the resulting EQSs for water therefore refer to concentrations of dissolved compounds. ${ }^{20}$ However, the EQS directive 2013/39/EU stipulates that the EQS for organic compounds refer to "total concentrations in the whole water sample”, for unspecified reasons. ${ }^{23}$

Technical guidance documents on chemical monitoring of surface waters ${ }^{10}$ and sediments/biota ${ }^{25}$ state that passive sampling can be used as a complementary method. The WFD allows member states to use alternative matrices for compliance monitoring if they define and use EQS values that are at least as protective as those specified in the EQS directive. However, the legally binding definition of organic contaminant EQSs in terms of total concentrations remains an obstacle for the use of passive sampling in compliance checking in the EU.

The key drivers in compliance monitoring of marine, coastal and transitional waters in the North-East Atlantic Ocean and its adjacent seas are the OSPAR Coordinated Environmental Monitoring Program (CEMP), ${ }^{26,27}$ the EU Marine Strategy Framework Directive (MSFD; coastal and marine waters only), ${ }^{28}$ and the WFD with its daughter directive on EQSs (transitional, coastal, and territorial waters). ${ }^{23}$ Regulations for chemical monitoring under the MSFD are still under discussion, but it is assumed that they will be based on those already established for the WFD, merged with the monitoring approaches by OSPAR and other regional seas conventions in the European area. Thresholds for the protection of marine systems are named Environmental Assessment Criteria (EAC) within OSPAR. These EACs are primarily based on aqueous toxicity data that have been recalculated to concentrations in sediments and biota using equilibrium partitioning (EqP) models. ${ }^{29}$ OSPAR recognizes the relevance of $C_{\text {free }}$ of nonpolar compounds for toxicity assessment, but requires contracting parties to monitor these compounds in biota and sediment, because these compounds cannot easily be measured in seawater due to their low concentrations. ${ }^{30}$ EACs are not legally binding, but instead are based on consensus among contracting parties, and can be adapted when additional knowledge becomes available. ${ }^{31}$

Chemical monitoring for checking compliance with National Pollutant Discharge Elimination System (NPDES) permit limits and for monitoring of ambient waters in the U.S. are regulated by the Clean Water Act (CWA). The CWA requires States to define Water Quality Standards (WQSs), which describe the designated uses of a water body, narrative and/or numerical Water Quality Criteria (WQC) that protect these uses, and antidegradation policies. Under Section 304(a) of the CWA, U.S. EPA publishes recommendations for WQC. States can either adopt these recommendations, modify them to account for site specific conditions, or use other scientifically defensible methods to develop their own WQC. State-adopted WQSs should be reviewed every three years, and are subject to approval by the federal EPA. ${ }^{32}$ In some cases the EPA can promulgate WQC for the states. WQC aim to protect sensitive species, similar to EQSs under the WFD. ${ }^{21}$ States monitor to assess attainment of WQS and identify impaired waters. If a waterbody is impaired, discharges are restricted to a total maximum daily load (TMDL).

Method Requirements. In the U.S., acceptable chemical analysis methods for compliance monitoring of effluents under the NPDES are listed in the Code of Federal Regulations, title 40 , part 136, but a permitting authority may specify the use of alternative methods. ${ }^{33}$ Passive sampling may not be the first method of choice for this type of compliance monitoring, because discharge permits are defined as TMDLs (i.e., concentrations in total effluent, multiplied by the daily effluent discharge volume). By contrast, method requirements for ambient water monitoring by the States are essentially unregulated by federal law, but instead result from the interaction between the U.S. EPA and a given State's department of environmental quality on how to assess water quality in relation to the WQC, using the best available practices. The Consolidated Assessment and Listing Methodology $(\mathrm{CALM})^{34}$ aims to continuously improve the quality of ambient water monitoring, using chemical, biological, and toxicological data, among others.

OSPAR and EU prescribe a number of criteria for chemical analysis and sampling to ensure that valid and comparable data are generated within monitoring programs (Table 1). ${ }^{24,27}$ Methods have to be documented and validated, and a quality assurance and control system needs to be in place to monitor and control data quality. WFD related methods have to be in accordance with EN/ISO/IEC 17025. Reference materials should be used, and laboratories must participate in proficiency testing schemes for the analytes of interest. Legally binding minimum performance requirements for chemical methods used in WFD monitoring are that the measurement uncertainty be $\leq 50 \%$ at the level of the EQS, and the limit of quantification $\leq 30 \%$ of the EQS. ${ }^{24}$ OSPAR does not specify quantitative requirements for these parameters, but requires that background assessment concentrations (BACs) for the target analytes in the sampled matrix be available. These BACs are derived from the mean and variance of long-term (10-year) concentration data for remote areas, as reported by participating laboratories. Measured concentration values are considered to be above background unless there is statistical evidence showing that it is near background. ${ }^{24,27}$

Method requirements for the application of PSDs in chemical monitoring of nonpolar compounds in a regulatory context are fulfilled to varying degrees (Table 1). Detailed guidelines for the use of PSDs are available for silicone sheet samplers ${ }^{35}$ and semipermeable membrane devices. ${ }^{2,36,37}$ ASTM International 
Table 1. Formal Requirements for Methods Used in Chemical Monitoring of Nonpolar Compounds in Water, for the Coordinated Environmental Monitoring Programme (CEMP) of the Oslo-Paris Convention for the Protection of the Marine Environment of the North-East Atlantic (OSPAR), the EU Water Framework Directive (WFD), and the U.S. Clean Water Act (CWA)

\begin{tabular}{|c|c|c|c|c|}
\hline \multirow[b]{2}{*}{ requirements } & \multicolumn{3}{|c|}{ required by } & \multirow[b]{2}{*}{ present status for passive sampling } \\
\hline & OSPAR & WFD & $\mathrm{CWA}^{a}$ & \\
\hline guidelines for passive sampling in water & yes & yes & yes & $\begin{array}{l}\text { available for silicone samplers }{ }^{35} \text { and SPMDs }{ }^{2} \\
\text { insufficiently available for low-density polyethylene, } \\
\text { poly(oxymethylene), and other PSDs }\end{array}$ \\
\hline $\begin{array}{l}\text { proficiency testing schemes (PTS) and } \\
\text { interlaboratory studies (ILS) }\end{array}$ & $\begin{array}{c}\text { yes } \\
\text { (PTS) }\end{array}$ & $\begin{array}{l}\text { yes } \\
\text { (PTS) }\end{array}$ & $\begin{array}{l}\text { yes } \\
\text { (ILS) }\end{array}$ & $\begin{array}{l}\text { PTS for silicone samplers is operational (www.quasimeme.org) } \\
\text { some interlaboratory comparisons available }{ }^{49-51}\end{array}$ \\
\hline certified reference materials & yes & yes & no & no CRMs available \\
\hline accuracy assessment & yes & yes & yes & general considerations available for nonpolar samplers ${ }^{52}$ \\
\hline background assessment concentrations & yes & no & no & available for PAHs, PCBs, $\mathrm{HCB}, \mathrm{DDE}^{53}$ \\
\hline water quality standards & $\begin{array}{c}\text { yes } \\
(\mathrm{EAC})\end{array}$ & $\begin{array}{c}\text { yes } \\
(\mathrm{EQS})\end{array}$ & $\begin{array}{c}\text { yes } \\
(\text { WQC })\end{array}$ & $\begin{array}{l}\text { OSPAR: in development (to be defined as } C_{\text {free }} \text { ) } \\
\text { EU: defined as } C_{\text {total }} \\
\text { USA: defined as } C_{\text {free }} \text { and } C_{\text {total }}\end{array}$ \\
\hline ISO standard & yes & yes & no & ISO $5667-23: 2011(E)^{46}$ \\
\hline QA/QC system & yes & $\begin{array}{c}\text { yes } \\
\text { (ISO 17025) }\end{array}$ & $\begin{array}{c}\text { yes } \\
{\text { (EPA guide-lines })^{b}}\end{array}$ & $\begin{array}{l}\text { QA/QC considerations available in the } \\
\text { guidelines above, and in ISO 5667-23:2011(E) }\end{array}$ \\
\hline
\end{tabular}

developed a standard method for SPME of polycyclic aromatic hydrocarbons (PAHs) in pore waters. ${ }^{38}$ Several interlaboratory studies that demonstrate method consistency are available, and are discussed below. A proficiency testing scheme organized by QUASIMEME is operational (www.quasimeme.org). Certified reference materials (CRMs) are presently not available, but CRM preparation for passive sampling could be easier than for batch water sampling. ${ }^{39}$ Data quality can be assessed from repeated analysis of CRMs (when available) or reference materials prepared by laboratories in-house, similar to current practice for the analysis of sediment and biota samples. Although Table 1 is focused on passive sampling in water, it can be envisioned that similar requirements exist for passive sampling in sediments.

In the U.S. context, ambient WQC for the protection of aquatic life against nonpolar compounds are based on toxicity tests with low organic carbon concentrations in the test water, and hence are essentially based on $C_{\text {free, }}$ albeit implicitly. ${ }^{40}$ WQC for the protection of human health are derived from chemical uptake by consumption (drinking water, fish/shellfish). Concentrations in fish/shellfish that are considered to be sufficiently protective are converted to aqueous concentrations using (preferably field derived) BAFs that are based on $C_{\text {free. }}{ }^{41}$ However, for use in WQC development, to be consistent with water quality monitoring data, these BAFs are converted back to values based on the total concentration. ${ }^{42,43}$ Thus, human health WQC cannot be directly compared with passive sampling results. Consequently, while regulators in the U.S. recognize the importance of $C_{\text {free, }}$ the actual water quality monitoring regulations do not yet use this parameter. OSPAR also aims to define water standards on a $C_{\text {free }}$ basis. ${ }^{30}$ Quality standards in the EU are commonly defined as $C_{\text {total }}$, but EU regulations allow the use of standards for other matrices if these offer an equal level of protection. Generic suspended particulate matter (SPM) contents of $15 \mathrm{mg} \mathrm{L}^{-1}$ (fresh waters) and $3 \mathrm{mg} \mathrm{L}^{-1}$ (marine waters) are recommended to convert between $C_{\text {free, }} C_{\text {total }}$ and concentrations in SPM. ${ }^{20,44,45}$ An ISO standard for the deployment, retrieval, and analysis of passive samplers is available, ${ }^{46}$ but guidance that is specific to particular sampler types and contaminant groups (e.g., polychlorinated biphenyls PCBs, PAHs, polychlorinated dibenzo-p-dioxins/furans - PCDD/ Fs) may have to be added in the future. This ISO standard also includes quality control measures to assess recoveries, precision, and method detection limits. Guidance for the selection, validation (QA/QC) and deployment of PSDs for contaminated sediments is also available. ${ }^{47}$

Differences in the monitoring approaches between the U.S. and OSPAR on one hand, and the EU on the other, will likely affect the further application of passive sampling in a regulatory context. In the U.S. context, States, U.S. EPA, and the research community cooperate in the CALM approach, to generate monitoring data that are best fit for a given purpose. ${ }^{34}$ Also OSPAR promotes the use of new technologies to amend existing methods for chemical monitoring. ${ }^{48}$ By contrast, monitoring in the EU is strongly regulated in legally binding directives that define EU-wide EQSs and specify method requirements for compliance checking with these EQSs.

To promote adoption of passive sampling into the implementation of compliance monitoring regulations, there is a critical need to get beyond passive sampling as a purely scientific endeavor and begin to standardize PSD type selection, deployment, chemical analysis, and data reporting. For example, in the United States, the lack of standardized methods has impeded greater acceptance of passive sampling in regulations. The following discussion reviews the progress made with passive sampling with regard to use in water, sediments, and biota. The discussion also emphasizes the areas in which passive sampling needs more work before standardizing can be successfully initiated. 


\section{PASSIVE SAMPLING IN WATER}

Target Compounds. The capability of PSDs for measuring aqueous concentrations of most nonpolar compounds $\left(\log K_{\text {ow }}>4\right)$ that are listed by OSPAR, U.S., and EU has been demonstrated, with detection levels in the low picogram per liter range. ${ }^{54}$ While most studies have focused on PAHs and globally regulated contaminants such as hexachlorobenzene (HCB), PCBs, organochlorine pesticides, $\mathrm{PCDD} / \mathrm{Fs}$, and polybrominated diphenyl ethers (PBDEs), ${ }^{55-58}$ a number of hydrophobic compounds of emerging concern have also been sampled by PSDs, including triclosan, ${ }^{37,59}$ alkylphenols, ${ }^{59}$ pyrethroids, ${ }^{60-62}$ cyclic methylsiloxanes, ${ }^{63}$ and organophosphates. ${ }^{58}$

Kinetic and Equilibrium Sampling Stages. Understanding the difference between the kinetic and the equilibrium sampling stage is important for a proper evaluation of the information that PSDs can and cannot provide. During the initial (kinetic) sampling stage, PSDs can be regarded as an infinite sink, and accumulated amounts of target compounds reflect the time weighted average concentrations over the deployment period. During prolonged exposure, the compounds gradually attain their equilibrium concentrations. All samplers go through a kinetic sampling stage, but equilibrium is not always reached on practical time scales for compounds with high sampler-water partition coefficients $\left(K_{\mathrm{sw}}\right)$, particularly for passive sampling in the water column, where the sampling rates $\left(R_{\mathrm{s}}\right)$ are usually smaller than for passive sampling in pore waters or biota. ${ }^{64-68}$ Equilibration times are generally shorter at higher water flow rates, lower $K_{s w}$ and higher area/volume ratios of the sampler, ${ }^{2,69}$ and typically range from days (e.g., endosulfan, $\log K_{\mathrm{ow}}=4$ ) to years (e.g., benzo[ghi]perylene, log $K_{\text {ow }}=6.5$ ) and beyond. ${ }^{54}$ Whether or not fast equilibration is desirable depends on the research question: long equilibration time scales may be desirable when a time-weighted average concentration is aimed for. Fast equilibration may be desired when studying the extent of equilibrium between pore waters and overlying waters, because equilibrium concentrations in the samplers can be directly compared (i.e., require no knowledge of the sampling kinetics). The options for optimizing equilibration time scales are limited to manipulation of the area/volume ratio, the choice of sampler material (higher or lower $K_{s w}$ for a particular compound), and flow rate. 70,71

Uptake Rate Control. Uptake rates of nonpolar compounds by PSDs can be limited by transport through the water boundary layer (WBL) or by the polymer, and the relative importance of these transport steps can be estimated from the polymer-water partition coefficient $K_{\mathrm{pw}}$ and the mass transfer coefficients of the $\operatorname{WBL}\left(k_{\mathrm{w}}\right)$ and the polymer $\left(k_{\mathrm{p}}\right)$. Specifically, $k_{\mathrm{w}} /\left(K_{\mathrm{pw}} k_{\mathrm{p}}\right) \ll 1$ is indicative of WBL controlled uptake and values $\gg 1$ indicate polymer control. ${ }^{2,69,72}$ Uptake rates of highly hydrophobic chemicals are usually limited by transport through the WBL, and weakly decrease with increasing molecular size. Polymercontrolled uptake is characterized by a strong decrease of $R_{s}$ with decreasing hydrophobicity. ${ }^{2,73-75}$ Models for $k_{\mathrm{p}}$ in singlephase PSDs typically rely on the assumption that $k_{\mathrm{p}}$ equals the diffusion coefficient of the chemical in the membrane divided by the half-thickness of the polymer. ${ }^{76-78}$ However, these models are approximate, because $k_{\mathrm{p}}$ decreases with time as the analytes diffuse further into the polymer, until a steady state value is attained. ${ }^{69,79}$ The compounds that show polymer controlled uptake typically have low $K_{\mathrm{sw}}$ values, and reach equilibrium relatively quickly. Models for partial and full polymer-controlled uptake are available, ${ }^{80}$ but are usually not needed for passive sampling of the water column, possibly with the exception of short-term exposures, ${ }^{81}$ very high water flow rates ${ }^{71}$ and in the case of polyoxymethylene (POM) samplers, for which diffusion coefficients in the polymer are more than an order of magnitude smaller than in low density polyethylene (LDPE) and 3 orders of magnitude smaller than in silicone. ${ }^{77,79,82,83}$ In addition, a comparison of silicone and LDPE samplers suggests that the uptake of PBDEs by LDPE may be polymer controlled to some extent. ${ }^{58}$

For WBL controlled uptake, hydrodynamic theory predicts $k_{\mathrm{w}}$ to be proportional to aqueous diffusion coefficient $\left(D_{\mathrm{w}}\right)$ to the power $2 / 3 .{ }^{84,85} D_{\mathrm{w}}$ has been correlated with molar volume, molecular weight, $K_{\mathrm{ow}}$, and $K_{\mathrm{sw}}$, and all of these models predict a similar decrease of $R_{s}$ with increasing molecular size. ${ }^{78}$ For example, the $R_{\mathrm{S}}$ of PCB180 is expected to be $1.2-1.5$ times smaller than the $R_{\mathrm{s}}$ of pyrene, depending on the model. ${ }^{86}$ The weak dependency of $R_{s}$ on molecular size was experimentally confirmed in some studies, ${ }^{75,78}$ but in other studies a stronger dependency was observed, which was modeled empirically as a polynomial regression of $\log R_{\mathrm{s}}$ versus $\log K_{\mathrm{ow}}{ }^{2,87}$ The strongerthan-expected decrease in $R_{s}$ with increasing $K_{o w}$ has been attributed to experimental artifacts due to sorption of analytes to dissolved organic matter in calibration setups, ${ }^{88}$ and the use of these models is therefore not recommended.

A value of $\log K_{\mathrm{ow}}=4.5$ is often used as a reference for the transition from polymer-controlled to $>50 \%$ WBL-controlled uptake. $^{2,81,89,90}$ However, this is an approximate value only, because the transition value depends on the hydrodynamic conditions, the diffusion coefficient in the polymer, and the polymer thickness. Thus, the transition to WBL-controlled uptake has been observed for SPMDs at $\log K_{\text {ow }}=5.5$ at flow rates of $90 \mathrm{~cm} \mathrm{~s}^{-1,75}$ and for uptake by LDPE samplers in sediment slurries at $\log K_{\mathrm{ow}}=6.5 .^{91}$ The $>100$ times higher diffusion coefficients in silicone compared with LDPE may explain WBLcontrolled uptake by silicone samplers for all compounds with log $K_{\text {ow }}$ values $>3{ }^{78,82}$

In Situ Calibration. The dependency of $R_{\mathrm{s}}$ on water flow velocity makes it necessary to either control the flow rate near the sampler ${ }^{5,92,93}$ or to calibrate the in situ uptake kinetics using the dissipation rates of performance reference compounds (PRCs)..$^{2,94-96}$ The PRC method is based on the consideration that the magnitude of $R_{\mathrm{s}}$ results from exposure-specific effects (flow, temperature, biofouling) and compound-specific effects (diffusion coefficients, $K_{\mathrm{sw}}$ ). In the original application of the PRC method, $R_{\mathrm{s}}$ were calculated for individual PRCs that show sufficient (e.g., > 20\%), yet not complete dissipation, in order to determine the exposure-specific effect. An $R_{s}$ model was used to calculate the $R_{\mathrm{s}}$ of compounds in the high-hydrophobicity range, for which PRCs show insufficient dissipation. ${ }^{2}$ In a later application, the exposure-specific effect was determined by nonlinear least-squares regression based on all PRC dissipation data, including PRCs that show insignificant or complete dissipation, ${ }^{52}$ thus allowing to determine uncertainties in $R_{s}$. The PRC method requires the use of an $R_{\mathrm{s}}$ model for calculating the $R_{\mathrm{s}}$ for compounds in the hydrophobicity range where PRCs show insignificant dissipation. These models can be empirical, ${ }^{2,87}$ semiempirical, ${ }^{75}$ or mechanistic. ${ }^{2,52,78}$ The use of mechanistic $R_{s}$ models is recommended, because the empirical models likely suffer from experimental artifacts, and semiempirical models must first be calibrated for particular contaminant classes. In a special application of PRCs, the degree of equilibrium for target analytes is calculated directly (i.e., without the use of any model) from the fractional dissipation of isotopically labeled analogues. ${ }^{93}$ 
In a modification of the latter approach, equilibrium attainment of target analytes is estimated from an empirical linear correlation of 100 minus the percentage of retained PRCs versus $\log K_{\text {ow }}{ }^{97}$ This approach may not be ideal, because the degree of equilibrium is not a linear function of $\log K_{\text {ow }}$, and because $\log K_{\mathrm{sw}}-\log K_{\mathrm{ow}}$ correlations may be compound class dependent. ${ }^{98,99}$ A relatively widespread idea is that PRCs must be mass-labeled analogues of the target analytes, ${ }^{100}$ but although this criterion is sufficient, it is too restrictive. Instead, the only requirement is that the PRCs should follow the same $R_{s}$ model as the target analytes. ${ }^{101}$

In situ calibration is not necessary for sampler designs in which the mass transfer resistance of the membrane is much larger than that of the water boundary layer; for example, membraneenclosed sorptive coating (MESCO) $)^{102}$ and ceramic dosimeters. ${ }^{103}$ This approach inevitably reduces the $R_{\mathrm{s}}$ and increases the detection limits, and therefore restricts the use of these samplers to highly contaminated sites.

Sampler-Water Partition Coefficients. The accuracy of $K_{\text {sw }}$ values is a key issue for compounds that reach the equilibrium sampling stage, since the errors in the estimated $C_{\text {free }}$ are linearly proportional to the errors in $K_{\mathrm{sw}}$. For compounds that remain in the kinetic sampling stage, $R_{\mathrm{s}}$ is the critical factor, and errors in $C_{\text {free }}$ measurements depend strongly on the errors in the $K_{\mathrm{sw}}$ of the PRCs, and not on the $K_{\mathrm{sw}}$ of the target analytes themselves. ${ }^{52}$ Dissolved salts cause $\log K_{\mathrm{sw}}$ to be higher in seawater (ionic strength $=0.72 \mathrm{~mol} \mathrm{~L}^{-1}$ ) than in fresh water by about $0.1-0.2 \mathrm{log}$ units, and a temperature decrease from 25 to $5{ }^{\circ} \mathrm{C}$ causes an increase in $\log K_{\mathrm{sw}}$ by about $0.1-0.7 \log$ units. ${ }^{76,104}$ Hydrostatic pressure may have an effect on $\log K_{\mathrm{sw}}$ that becomes noticeable below a few hundred meters water depth. ${ }^{105}$

The experimental determination of $K_{\mathrm{sw}}$ values of nonpolar compounds is not a trivial task, as is evidenced by the high interlaboratory variability of $0.2-0.5$ log units. ${ }^{76,90,106}$ This gives rise to errors in the estimated $C_{\text {free }}$ by factors of 1.6-3. We recommend to use stricter protocols for the determination of $K_{\mathrm{sw}}$ and, for quality control purposes, to include a limited number of compounds with well-established $K_{\mathrm{sw}}$ values for new $K_{\mathrm{sw}}$ experiments. The selection and use of reference polymers can also be considered for documenting the accuracy of $K_{\mathrm{sw}}$ determinations. Further, considering that polymer-polymer partition coefficients are within 1 order of magnitude from unity, and therefore easier to measure than $K_{\mathrm{sw}}$, the use of a reference polymer may help to harmonize $K_{\mathrm{sw}}$ values for different polymers, and may help to better address between-manufacturer and between-batch variability of the polymers used. Application of this approach showed that the manufacturer effect on $K_{\mathrm{sw}}$ for five silicone sheets ranged between 0.2 and 0.6 log units, and that the $K_{\mathrm{sw}}$ for three batches from the same manufacturer differed less than 0.09 log units ${ }^{98}$

Due to the difficulty of measuring $K_{\mathrm{sw}}$, several authors have suggested to report equilibrium concentrations in a reference polymer (e.g., poly(dimethylsiloxane) - PDMS) or reference lipid as target parameters in addition to $C_{\text {free }}$, because these concentrations are also linearly proportional to chemical activity. ${ }^{107-109}$ In this approach, $K_{\mathrm{sw}}$ is not needed since the monitoring results are reported as concentrations in the reference polymer or the reference lipid. Concentrations in the reference lipid are calculated from concentrations in the polymer and the polymer-lipid partition coefficients. The latter are easier to measure than $K_{\mathrm{sw}}$ due to their lower values. The conversion of aquatic toxicity thresholds from $C_{\text {free }}$ to equilibrium concentrations in a reference polymer allows the use of these concentrations within a regulatory context. Although this approach is scientifically sound, it requires a change of paradigm that is not easily accomplished, and accurate $K_{\mathrm{sw}}$ values are still needed for the conversion of toxicity data that have been published as total dissolved concentrations or $C_{\text {free }}$. Further, practical difficulties with reference polymers or lipids are that the scientific community has to agree on phases for which all target analytes reach equilibrium within a reasonable time frame. Rapid equilibrium attainment can be accomplished for passive sampling in sediments and in lipid-rich phases, but generally not for passive sampling in the water column, where equilibrium attainment for compounds with $\log K_{\mathrm{ow}}$ values $>5.5$ is not often observed.

Uncertainties. The EU's directive on technical specifications for chemical analysis and monitoring of water status requires a measurement uncertainty of $\leq 50 \%(k=2)$ at the level of the EQS. ${ }^{24}$ It should be noted that the main error source for $C_{\text {free }}$ is not in the chemical analysis of the PSD matrix, but in the $K_{\mathrm{sw}}$ values used in the calculations thereafter (see above). Further, the uncertainty in $C_{\text {free }}$ remains fairly constant down to the level where the amounts in exposed PSDs approach the amounts that are present in the field control samplers (i.e., $\sim 10 \mathrm{pg} \mathrm{L}^{-1}$ or lower). ${ }^{54}$ In addition, several water EQS values for nonpolar compounds are set at the pg $\mathrm{L}^{-1}$ level (e.g., cypermethrin) or below, and it is difficult to imagine how compliance with these EQS can be demonstrated without PSDs. Moreover, the timeintegrative nature of passive sampling makes this method less sensitive to short-term temporal variation than batch sampling. Finally, it should be considered that QA/QC measures that are typically taken for the chemical analysis of other matrices can also be applied to PSDs, including the determination of recoveries, procedure blanks, quantitation and detection limits, the analysis of CRMs and the participation in laboratory performance studies. $^{46}$

The accuracy of PSD based $C_{\text {free }}$ determinations can be assessed from PSD comparisons, which should all yield the same values. A field deployment of seven PSDs in the river Meuse showed that $C_{\text {free }}$ estimates from SPMDs, silicone, and LDPE strips were in agreement within a factor of 2, with somewhat larger deviations for Chemcatcher, MESCO and silicone rods. ${ }^{49}$ In a PSD comparison in the laboratory, the calculated $C_{\text {free }}$ agreed with nominal concentrations within a factor of 2 for SPMDs, silicone, and LPDE strips, with low values for LDPE and high values for silicone, on average. ${ }^{110}$ Results for POM and thinfilm PDMS samplers that were exposed in a Norwegian Fjord agreed within a factor of $2-3 .{ }^{111}$ Calculated $C_{\text {free }}$ of PAHs were 3 times higher for POM than for LDPE samplers exposed in Narragansett Bay, while the reverse was found for PCBs. ${ }^{97}$ Concentrations of $o, p^{\prime}$-DDE and $p, p^{\prime}$-DDE derived from LDPE samplers were about 3 times higher than SPME based concentrations. ${ }^{112}$ Results from an interlaboratory study for PAH passive sampling that included 22 laboratories using five sampler types, showed a coefficient of variation (CV) in $C_{\text {free }}$ of $90 \%$, and mean PSD based concentrations that were two times higher than results based on batch sampling. ${ }^{51}$ No relationship between $C_{\text {free }}$ and sampler type was observed in this study, suggesting that the chemical analysis of the sampler and/or the chosen method of $C_{\text {free }}$ calculation are important sources of variability. Results from the NORMAN interlaboratory study on passive sampling (www.norman-network.net) showed that $R_{\mathrm{s}}$ estimation is a major error source ( $\sim$ factor 25$)$ for the reported $C_{\text {free }}$ of PBDEs (14 laboratories), followed by the chemical analysis of target compounds and PRCs in the sampler ( factor 4$).{ }^{50}$ The ICES Passive Sampling Trial Survey identified chemical analysis 
(20-40\%) and $R_{\mathrm{s}}$ estimation (30\%) to be the main sources of interlaboratory variability of reported $C_{\text {free }}$ values of PAHs and PCBs. ${ }^{113}$ Between-laboratory CVs for the chemical analysis of PSDs are at the lower end of CVs for the analysis of PCBs in biological materials (14-117\%), PCBs in sediments (21-59\%), and PAHs in sediment and mussel (23-62\%). ${ }^{114-116}$ The results from interlaboratory studies imply that standardization of $R_{\mathrm{s}}$ estimation methods, improvement of analytical techniques, and the selection of consensus values for $K_{\mathrm{sw}}$ may greatly reduce interlaboratory variability of passive sampling results. It can therefore be expected that participation in laboratory performance studies that focus on chemical analysis of PSDs and on calculation methods will reduce between-laboratory variability for two reasons. First, such studies will force laboratories to continuously and critically assess their analytical methods. Second, a comparison of calculation methods will reveal if any inappropriate $C_{\text {free }}$ calculation methods are being used. The observed differences in $C_{\text {free }}$ estimates are not surprising in view of the inaccuracies in $K_{\mathrm{sw}}$ values and the occasional use of empirical $R_{\mathrm{s}}$ models. ${ }^{49,117}$ This stresses the importance of improving the experimental determination and theoretical evaluation of $K_{\mathrm{sw}}$ and $R_{\mathrm{s}}$ as well as developing robust guidelines for not only chemical analysis but also $C_{\text {free }}$ calculation.

Comparisons of passive sampling with batch water sampling followed by filtration and extraction provide additional information about passive sampling accuracy. However, results from these studies are difficult to interpret, because of the differences of the targeted concentrations (freely dissolved versus total dissolved), the time-integrative nature of passive sampling data, and because filtration/extraction methods have their own difficulties, such as contaminant adsorption to equipment surfaces, and filtration efficiencies that vary with the extent of filter clogging. ${ }^{118,119}$

Results from passive sampling with SPMDs, POM, and silicones generally agree within a factor of 3 with results from batch sampling ${ }^{119-125}$ although differences by a factor of $\sim 10$ have also been observed. ${ }^{111,126}$ In some cases, differences increased with hydrophobicity, which could be attributed to the contribution of dissolved organic carbon (DOC) bound compounds to batch sampling based results. ${ }^{121,123,125}$

\section{PASSIVE SAMPLING IN SEDIMENTS}

The 2012 SETAC technical workshop "Guidance on Passive Sampling Methods to Improve Management of Contaminated Sediments" reviewed the knowledge on passive sampling of nonpolar organic compounds and trace metals in sediments. ${ }^{127,128}$ There was general agreement that $C_{\text {free }}$ of nonpolar compounds is a better proxy of sediment toxicity and bioaccumulation in benthic invertebrates than total concentrations in the sediment, ${ }^{12,129-132}$ and that passive sampling is a better method for obtaining $C_{\text {free }}$ than EqP calculations utilizing sorption to amorphous and black carbon. ${ }^{130,133}$ The SETAC workshop also noted that the uncertainties in $C_{\text {free }}$ span several orders of magnitude for EqP calculations, and 1 order of magnitude for direct measurement with PSDs. ${ }^{127,130}$ The preferred strategy for obtaining $C_{\text {free }}$ from ex situ passive sampling in sediments was to allow compounds to reach equilibrium with the sampler, because $C_{\text {free }}$ can then be directly calculated from $K_{\mathrm{sw}^{*}}{ }^{47,127,129,130}$ It was also noted that equilibrium may be difficult to attain at reasonable time scales for some very hydrophobic compounds at least when sampling in situ, and that kinetic models may be needed in those cases. ${ }^{129}$ With passive sampling in stirred sediments (ex situ) the same first-order kinetic uptake models that are used in passive water sampling may be applied ${ }^{47,91,129,134}$ while more complex models are needed for sampling in unstirred (in situ) sediments. ${ }^{91,130,135-137}$ Parallel sampling with multiple coating thicknesses are increasingly used to confirm attainment of equilibrium, while at the same time checking for additional quality assurance criteria (negligible depletion, absence of surface related artifacts). ${ }^{109,138}$ The SETAC workshop noted further that the main sources of error for passive sampling in sediments are the inaccuracies in the $K_{\mathrm{sw}}$ values, and the possible underestimation of equilibration times, particularly for in situ applications. ${ }^{130}$ Practical guidance on the use of PSDs for measuring $C_{\text {free }}$ in sediments was summarized, including the choice of sampler type, in situ versus ex situ application, sampler calibration, experimental design, assessment of equilibrium attainment, QA/QC issues, and the use of passive sampling in tiered risk assessments. ${ }^{47}$

Bioaccessibility and Chemical Activity. Passive sampling can be used as a depletive method for measuring the (readily) desorbing contaminant fraction of the sediment as a measure of bioaccessibility, or as a negligible-depletion method for $C_{\text {free }}$ as a measure of chemical activity. ${ }^{139,140}$ The 2012 SETAC workshop focused for practical reasons on $C_{\text {free }}$ but also recognized the relevance of passive sampling for evaluating bioaccessibility. Depletive sampling of sediment slurries with poly(2,6-diphenyl$p$-phenylene oxide) (Tenax) has been used to separate contaminant fractions that show rapid, slow, and very slow desorption rates. ${ }^{141,142}$ It has been suggested that high organic carbon-water partitioning coefficients can be quantitatively explained by the occurrence of a (very) slowly desorbing contaminant fraction. ${ }^{142,143}$ Further, the available evidence suggests that contaminant toxicity and body burden for benthic organisms are linked both to concentrations in SPME fibers at equilibrium and to the rapidly desorbing fraction as determined with the Tenax method. ${ }^{144}$ Tenax and SPME performed equally well in explaining bifenthrin toxicity to chironomids and crustaceans for three sediments that spanned a 5 fold difference in organic carbon content. ${ }^{145}$ Smedes et al. developed a passive sampling approach for measuring both accessibility and $C_{\text {free }}$ by incubating sediments and silicone sheets at multiple polymer/ sediment mass ratios. ${ }^{66}$ At low ratios, this method yielded $C_{\text {free }}$ (no depletion of the sediment phase). At high ratios the accessible contaminant pool in the sediment phase could be quantified (maximum depletion).

\section{LINKING PASSIVE SAMPLING TO CONCENTRATIONS IN BIOTA}

Maximum protection of aquatic species, humans, and predators is achieved by monitoring all relevant matrices (water, food, prey organisms, respectively) but this would be very costly. It is therefore common practice to limit the number of matrices that are monitored, and to establish relationships between concentrations in water and in biota in order to compare quality standards derived for the protection targets (aquatic organisms, predators and humans). ${ }^{20}$ Whether passive sampling or biota monitoring is the preferred method therefore depends on their respective relevance for the species that is to be protected and on the uncertainties involved in estimating concentration levels in water from those in biota and vice versa. Below, we will discuss established biota-PSD relationships and the performance of PSDs and biota monitoring for assessing $C_{\text {free, }}$ spatial and temporal trends, and predator diet.

Biota-PSD Relationships. Passive sampling research has shown that BAFs and $K_{\mathrm{ow}}$ follow a log-log linear relationship when the BAFs are based on $C_{\text {free }}$ rather than on total dissolved 
concentrations, and that the frequently reported nonlinearity in $\log$ BAF at high $\log K_{\mathrm{ow}}$ is in fact artificial. ${ }^{146,147}$ Passive sampling based linear log BAF- $\log K_{\mathrm{ow}}$ relationships have been observed for bioaccumulation of nonpolar compounds $\left(3<\log K_{\mathrm{ow}}<7.5\right)$ by oligochaetes, ${ }^{146,148,149}$ midge larvae, ${ }^{150}$ and blue mussels. ${ }^{151}$

Many studies show correlations between measured concentrations in PSDs and aquatic animals. Strong correlations have, for instance, been observed between lipid-based concentrations of organochlorine pesticides, PAHs and PCBs in biota and equilibrium concentrations in thin $(<0.05-0.5 \mu \mathrm{m})$ films of poly(ethylene-co-vinyl acetate) (EVA) for earthworms, ${ }^{152}$ bivalves, ${ }^{153}$ and amphipods. ${ }^{154}$ Lipid-EVA concentration ratios ranged between 0.1 and 0.8 , and similar ratios $(\sim 0.5)$ were observed with in vitro sampling of rainbow trout homogenates with EVA. ${ }^{155}$ Lipid normalized PCB concentrations in polychaetes were also strongly correlated with equilibrium concentrations in LDPE, with polychaete/PSD concentration ratios ranging from about 1 to $20 .^{156,157}$ Weaker correlations (log-log slope of 0.6) and site-specific concentration ratios were observed for PAHs in polychaetes and LDPE. ${ }^{158}$ Concentrations of PAHs and organochlorine pesticides in mussels were positively correlated with $C_{\text {free }}$ that were obtained from SPME and LDPE samplers, but correlations for PCBs were much weaker. $^{60}$

It is also possible to predict EqP concentrations in biota. One approach is to predict lipid based biota concentrations as the product of $C_{\text {free }}$ and BAF values, ${ }^{149,159-161}$ where some studies used $K_{\text {ow }}$ as surrogate for BAF. ${ }^{162-165}$ This approach yielded predicted lipid based concentrations of PCBs and PAHs in earthworms and oligochaetes that were generally within a factor of 3 of measured lipid normalized concentrations. This is a surprisingly good agreement, considering that uncertainties in $\mathrm{BAF}, K_{\mathrm{ow}}$, and $K_{\mathrm{sw}}$ all contribute to the error in the predicted $\mathrm{EqP}$ concentrations. Another approach is to determine EqP concentrations in lipids from the product of measured equilibrium concentrations in the passive sampling polymer and lipid to polymer partition coefficients. ${ }^{138,166,167}$ This approach resulted in $\mathrm{EqP}$ concentrations in lipids, which were either near or higher than actually measured concentrations in biota. This was observed for benthic worms, ${ }^{138}$ mussels, and several fish species. ${ }^{109,167-169}$ A close correspondence between passive sampling based $C_{\text {free }}$ and concentrations in mussels for PAHs and PCBs was observed in a monitoring study over four years, two sampling seasons, and eight estuarine and coastal stations. ${ }^{151}$ Calculated log BAF values showed a scatter of $\sim 0.2 \log$ units, indicating that concentrations in mussels can be predicted from PSD based $C_{\text {free }}$ with a similar precision.

Chemical Activity. It is widely recognized that $C_{\text {free }}$ is a valuable proxy for chemical activity, because knowledge of these concentrations allows estimation of the equilibrium concentrations in other environmental compartments (sediments, air, biota). ${ }^{12,20,90,132,170}$ Measured chemical activities in sediment and overlaying water allow a direct assessment of whether the sediment acts as a diffusive source or sink, since diffusive mass transfer always goes from high to low chemical activity. Chemical activity can be measured with passive sampling, either as ratio of $C_{\text {free }}$ and subcooled liquid solubility or as product of $C_{\text {free }}$ and activity coefficient. Witt et al. have for instance used ex situ passive sampling with silicone coated glass fibers to determine depth profiles of chemical activity for PAHs at three locations in the Baltic Sea. ${ }^{171}$ For equilibrium sampling, ratios of chemical activity can be determined very easily as concentration ratios on a polymer basis.
Passive sampling of biota tissue and extracted lipids is a recent application that allows for a direct assessment of chemical activity in biota. ${ }^{67,68,138,166,172,173}$ With this method, a polymer is equilibrated with biota tissue, tissue homogenate, or lipid extract, by immersion or via a headspace. Typical equilibration times are in the order of hours for PCBs and PAHs in fat-rich tissues. ${ }^{67,172,173}$ Contaminant concentrations in the polymer are directly proportional to the chemical activity, and comparison of these concentrations therefore allows for directly comparing chemical activities. For instance, Jahnke et al. applied equilibrium sampling to sediment and eel tissue from a Swedish lake, and showed the eel to be under-equilibrated relative to the sediment. ${ }^{168}$ Allan et al. compared equilibrium concentrations in silicone samplers that were exposed to water with samplers that were exposed to fish tissue in vivo. ${ }^{68}$ Concentration ratios were $\sim 1$ for hexachlorobenzene and PCBs as well as for some three-ring PAHs, reflecting a significant degree of fish-water equilibrium for these compounds.

Biota monitoring is less suitable for estimating $C_{\text {free }}$ and chemical activity, because the required BAFs show a high variability among studies, even for the same species. ${ }^{45,174}$ Furthermore, a review of $>7000$ BAF values showed that $45 \%$ of the data suffered from one or more major sources of uncertainty. ${ }^{175}$

Spatial and Temporal Trends. Biota monitoring has been used extensively to assess spatial and temporal trends of contamination by nonpolar compounds and trace metals. ${ }^{176-179}$

The limitations of using sentinel organisms for comparing contamination levels in time and space are generally recognized. Multiple species may be needed for obtaining a good geographical coverage (e.g., oysters, blue mussels, green mussels, zebra mussels), and sometimes may not be available (e.g., offshore environments, deep sea, anoxic or toxic locations), and several biotic and abiotic factors have to be accounted for. ${ }^{180,181}$ These issues do not exist for PSDs when results are expressed as $C_{\text {free }}$ (rather than as an accumulated amount per unit sampler mass). When a transition from biota to PSD-based trend monitoring is considered, it is important to determine appropriate biota-PSD conversion factors, in order to ensure data continuity. An evaluation of nine mussel-SPMD comparison studies suggested that BAF values were the major source of variability of $\mathrm{SPMD} /$ mussel concentration ratios, and that site-specific repetitive parallel exposures are needed to convert historical biomonitoring data to current passive sampling data. ${ }^{174}$ The 4-y mussel-PSD comparison study mentioned above showed that the transition of biota monitoring time series (using bivalves) to passive sampler based time series is feasible. ${ }^{151}$

Predator Diet. Under the WFD, EQS values in biota $\left(\mathrm{EQS}_{\text {biota }}\right)$ are defined for hydrophobic and other substances (e.g., $\mathrm{Hg}$ ) where risks of secondary poisoning and risk for human health via fish consumption cannot be excluded. ${ }^{20}$ In the most current revision of the EQS directive most of these substances have to be monitored in fish, except for PAHs (crustaceans and molluscs), and dioxins as well as dioxin-like PCBs (fish, crustaceans and molluscs), but other organisms can be used if EQSs for these alternative organisms offer the same level of protection. ${ }^{23}$ Some promising relationships have been established for legacy contaminants between equilibrium concentrations in PSDs and biota, including fish (see above). However, the WFD requires monitoring of other substances in fish (e.g., $\mathrm{Hg}$, hexachlorobutadiene - HCBD, dicofol, hexabromocyclododecane -HBCDD), and the suitability of PSDs to predict concentrations of these compounds in fish is still unclear. Bioaccumulation 
models for aquatic species at trophic levels up to and including predatory fish provide a mechanistic link between the concentrations in biota and concentrations in the water phase, ${ }^{170}$ although reliable species- and compound- specific BAF values are required. These can be scarce or even absent. ${ }^{175}$ These considerations imply that setting water based thresholds for the protection of predators is in principle valid, but direct monitoring of prey organisms may still be required because of the uncertainties in the BAF values that are used. We recommend that biota based monitoring be supplemented by passive sampling, because this allows the generation of valuable field-based BAF values that would improve modeling of contaminant transfer to the higher trophic levels. Such data would also be helpful for establishing biota-PSD relationships for pelagic species, which are presently scarce. $^{182}$

\section{THE WAY FORWARD}

Much progress has been made in the field of passive sampling for environmental monitoring of nonpolar compounds in the aquatic environment, since the introduction of passive sampling in the early 1990s. This is notably the case for the risk assessment of contaminated sediments, where passive sampling based $C_{\text {free }}$ has proven superior to the use of concentrations in whole sediment or partitioning based modeling approaches for the various organic carbon pools, both with respect to sediment toxicity and bioaccumulation. Significant progress has also been made for passive water sampling, with the development of mechanistic sampler-water exchange models and improved in situ calibration. Yet, not all claims that have been made by the passive sampling community with respect to accuracy, have been demonstrated beyond doubt. Insufficient quality control presently appears to be a dominant weakness of passive sampling, and progress can be expected from laboratory performance studies that include a detailed assessment of the sources of variability in the reported results. Inaccuracies in the $K_{\mathrm{sw}}$ of target analytes (in the case of equilibrium passive sampling) and PRCs (kinetic sampling) are a major source of concern. The determination of these partition coefficients is more difficult than generally assumed, and scientific journals could be less permissive in admitting data obtained from single experiments, even when these are carried out in triplicate. Researchers should carefully consider this issue before introducing new passive sampling matrices for nonpolar compounds.

The tight connection between PSD-based $C_{\text {free }}$ and lipidnormalized concentrations in biota suggests that passive sampling can be used to predict $C_{\text {biota }}$ to a fair or good degree for organisms at lower trophic levels. More research is needed to assess how passive sampling measurements can best be linked to concentrations at higher levels of the aquatic food web. The combination of passive sampling and bioaccumulation models seems then the most effective approach for assessing and predicting bioaccumulation.

Passive sampling inside biota, or in biota homogenates and lipid extracts, is a promising method for assessing the degree of equilibrium between biota and their environment. More research in this field is required, particularly with respect to passive sampling in biota with low lipid content, and for compounds other than PCBs and PAHs.

The capabilities of passive sampling are not fully utilized in a regulatory context by environmental managers, particularly in the EU. This is partly due to the scientific community, which may have overrated the achievements of passive sampling research in the past, and may have shown insufficient concern for the legal and practical context in which environmental managers operate, including quality control procedures. The community of environmental managers on its part could make more efforts in comparing the pros and cons of passive sampling based monitoring with the pros and cons of current approaches, with respect to scientific justification, uncertainty (including sampling uncertainty), and relevance for environmental risk assessment.

In Europe, the strict monitoring requirements laid down in the EU WFD and its daughter directives impede the implementation of passive sampling for regulatory purposes, whereas environmental managers in the United States and in OSPAR have more freedom to adapt management approaches to current scientific insights.

Specifically, in the United States, the use of passive sampling in the implementation of ambient water monitoring and remediation processes for contaminated sediments has been encouraged by regulators. This encouragement is based on the recognition that passive sampling-based $C_{\text {free }}$ data provides a better scientific basis for risk assessment, compared with conventional sampling and monitoring procedures. The actual use of passive sampling is limited by the current lack of commercial laboratories performing passive sampler deployments, chemical analyses, and data reporting. Hesitancy by many commercial laboratories is linked to the current lack of standardized methods and procedures for using PSDs. In the near future, the scientific community will be crucial in providing guidance on the standardization of passive sampling methods. We expect that an open and critical communication between scientists and environmental managers will be beneficial for both.

\section{ASSOCIATED CONTENT}

\section{S Supporting Information}

The Supporting Information is available free of charge on the ACS Publications website at DOI: 10.1021/acs.est.5b04050.

Types and configurations of passive samplers for nonpolar organic compounds (PDF)

\section{AUTHOR INFORMATION}

\section{Corresponding Author}

*Phone +31 222369 463; fax +31 222319 674; e-mail kees.booij@nioz.nl.

\section{Notes}

The authors declare no competing financial interest.

\section{ACKNOWLEDGMENTS}

We acknowledge the International Council for the Exploration of the Sea (ICES) for initiating the 2013 "Workshop on the Application of Passive Sampling and Passive Dosing to Contaminants in Marine Media”, which formed the starting point for the present review. The content of this article does not necessarily represent the position of ICES. Foppe Smedes acknowledges support from the Czech Ministry of Education (LO1214 and LM2011028), and Philipp Mayer from the U.S. Strategic Environmental Research and Development Program (14 ER03-035/ER-2431). Mention of trade names or commercial products does not constitute endorsement or recommendation for use. This report has been reviewed by the U.S. EPA's Office of Research and Development, National Health and Environmental Effects Research Laboratory, Atlantic Ecology Division, Narragansett, RI, and approved for 
publication. Approval does not signify that the contents necessarily reflect the views and policies of the Agency.

\section{GLOSSARY}

BAC Background Assessment Concentration, threshold concentration that is considered to indicate that measured concentrations represent natural background levels (OSPAR)

BAF Bioaccumulation factor, concentration in biota divided by concentration in water at steady state, resulting from all uptake and elimination processes, including bioconcentration, biomagnification, biotransformation, and growth dilution

$C_{\text {free }}$ concentration of freely dissolved compounds in the water phase

$C_{\text {total }}$ total concentration of compounds, including freely dissolved compounds and compounds that are bound to particles and colloids

CWA Clean Water Act (U.S.)

EAC Environmental Assessment Criteria, threshold concentrations that are considered to cause no unacceptable adverse effects on biota or human health (OSPAR)

EQS Environmental Quality Standard, threshold concentration that is considered to cause no unacceptable adverse effects on biota or human health (EU)

$k_{\mathrm{w}} \quad$ mass transfer coefficient of the water boundary layer at the PSD-water interface

$k_{\mathrm{p}} \quad$ mass transfer coefficient in the polymer

$k_{\mathrm{o}} \quad$ overall mass transfer coefficient of the water boundary layer

$K_{\text {ow }} \quad$ 1-octanol - water partition coefficient

$K_{\mathrm{pw}} \quad$ polymer - water partition coefficient

$K_{\mathrm{sw}} \quad$ sampler - water partition coefficient

MSFD Marine Strategy Framework Directive (EU)

OSPAR Oslo-Paris Convention for the protection of the marine environment of the North-East Atlantic

$R_{\mathrm{s}} \quad$ water sampling rate

PSD passive sampling device

WQC Water Quality Criteria, narrative and/or numerical indicator of water quality that is considered to cause no unacceptable adverse effects on biota or human health (U.S.)

WQS Water Quality Standard, description of designated uses of a water body, WQC that protect these uses, and antidegradation policies (U.S.)

WFD Water Framework Directive (EU)

\section{REFERENCES}

(1) Kot, A.; Zabiegala, B.; Namiesnik, J. Passive sampling for long-term monitoring of organic pollutants in water. TrAC, Trends Anal. Chem. 2000, 19, 446-459.

(2) Huckins, J. N.; Petty, J. D.; Booij, K. Monitors of Organic Chemicals in the Environment: Semipermeable Membrane Devices; Springer: New York, 2006.

(3) Stuer-Lauridsen, F. Review of passive accumulation devices for monitoring organic micropollutants in the aquatic environment. Environ. Pollut. 2005, 136, 503-524.

(4) Vrana, B.; Mills, G. A.; Allan, I. J.; Dominiak, E.; Svensson, K.; Knutsson, J.; Morrison, G.; Greenwood, R. Passive sampling techniques for monitoring pollutants in water. TrAC, Trends Anal. Chem. 2005, 24, $845-868$.

(5) Ouyang, G. F.; Pawliszyn, J. Configurations and calibration methods for passive sampling techniques. J. Chromatogr. A 2007, 1168, $226-235$.
(6) Namiesnik, J.; Zabiegala, B.; Kot-Wasik, A.; Partyka, M.; Wasik, A. Passive sampling and/or extraction techniques in environmental analysis: a review. Anal. Bioanal. Chem. 2005, 381, 279-301.

(7) Greenwood, R.; Mills, G.; Vrana, B. Passive Sampling Techniques in Environmental Monitoring; Elsevier: Amsterdam, 2007.

(8) Arthur, C. L.; Pawliszyn, J. Solid Phase Microextraction with thermal desorption using fused silica optical fibers. Anal. Chem. 1990, $62,2145-2148$.

(9) Huckins, J. N.; Tubergen, M. W.; Manuweera, G. K. Semipermeable membrane devices containing model lipid: a new approach to monitoring the bioavailability of lipophilic contaminants and estimating their bioconcentration potential. Chemosphere 1990, 20, 533-552.

(10) EU. Guidance on surface water chemical monitoring under the water framework directive. Common implementation strategy for the Water Framework Directive (2000/60/EC). Guidance Document No. 19, Technical Report 2009-025; Office for Official Publications of the European Communities: Luxembourg, 2009, http://dx.doi.org/10. 2779/72701.

(11) ECHA. Principles for environmental risk assessment of the sediment compartment. In Proceedings of the topical scientific workshop. Helsinki, 7-8 May 2013, ECHA-14-R-13-EN; European Chemicals Agency: Helsinki, 2014, http://echa.europa.eu/documents/10162/ 13639/environmental risk assessment final en.pdf.

(12) Burgess, R. M.; Berry, W. J.; Mount, D. R.; Di Toro, D. M. Mechanistic sediment quality guidelines based on contaminant bioavailability: Equilibrium partitioning sediment benchmarks. Environ. Toxicol. Chem. 2013, 32, 102-114.

(13) ITRC. Technology Overview of Passive Sampler Technologies., DSP4; Interstate Technology \& Regulatory Council, Authoring Team., Washington, DC, 2006, http://www.itrcweb.org/ GuidanceDocuments/DSP 4.pdf.

(14) U.S. EPA. Guidelines for Using Passive Samplers to Monitor Organic Contaminants at Superfund Sediment Sites., OSWER Directive 9200.1110 FS.; United States Environmental Protection Agency, Office of Superfund Remediation and Technology Innovation, and Office of Research and Development, Washington, DC, 2012. https://clu-in.org/ download/contaminantfocus/sediments/Sediments-Passive-SamplerSAMS 3.pdf.

(15) U.S. EPA. Equilibrium Partitioning Sediment Benchmarks (ESBs) For the Protection of Benthic Organisms: Procedures for the Determination of the Freely Dissolved Interstitial Water Concentrations of Nonionic Organics, EPA/600/R-02/012; Office of Research and Development, Washington, DC 20460, 2012. http://cfpub.epa.gov/si/si_public_file_ download.cfm?p download id $=513400$.

(16) Smedes, F.; van der Zande, A.; Roose, P.; Davies, I. M. ICES passive sampling trial survey for water and sediment (PSTS) 20062007. Part 3: preliminary interpretation of field data. ICES Annual Science Conference, Helsinki, 17-21 September. http://www.ices.dk/ sites/pub/CM\%20Doccuments/CM-2007/J/J0407.pdf.

(17) Larsen, M. M.; Allan, I. J.; Naes, K.; Nyberg, E.; Hoydal, K. Evaluation of passive samplers for the monitoring of contaminants in sediment and water: Monitoring of POPs and PCBs in international monitoring programmes., TemaNord 2009:563; Nordic Council of Ministers: Copenhagen, 2009; http://norden.diva-portal.org/smash/ get/diva2:702813/FULLTEXT01.pdf.

(18) OSPAR. Status and Trend of Marine Chemical Pollution, Publication Number: 395/2009; OSPAR Commission, London, 2009; http://www.ospar.org/documents?v=7199.

(19) ICES. Report of the Workshop on the Application of Passive Sampling and Passive Dosing to Contaminants in Marine Media (WKPSPD), ICES CM 2013/SSGHIE:02; ICES: Copenhagen, 2013; http://www.ices.dk/ sites/pub/Publication\%20Reports/Expert\%20Group\%20Report/ SSGHIE/2013/WKPSPD13.pdf.

(20) EU. Technical Guidance For Deriving Environmental Quality Standards. Common implementation strategy for the Water Framework Directive (2000/60/EC). Guidance document No. 27, Technical Report 2011-055; European Communities, 2011. http://dx.doi.org/10.2779/ 43816. 
(21) U.S. EPA. Water Quality Standards Handbook, 2nd ed.; 2014. http://water.epa.gov/scitech/swguidance/standards/handbook/.

(22) EU Directive 2000/60/EC of the European Parliament and of the Council of 23 October 2000 establishing a framework for Community action in the field of water policy. Off. J. Eur. Union 2000, L327, 1-72.

(23) EU Directive 2013/39/EU of the European Parliament and of the council of 12 August 2013 amending Directives 2000/60/EC and 2008/ $105 / \mathrm{EC}$ as regards priority substances in the field of water policy. Off. J. Eur. Union 2013, L226, 1-17.

(24) EU Commission Directive 2009/90/EC of 31 July 2009 laying down, pursuant to Directive 2000/60/EC of the European Parliament and of the Council, technical specifications for chemical analysis and monitoring of water status. Off. J. Eur. Union 2009, L210, 36-38.

(25) EU. Guidance on chemical monitoring of sediment and biota under the Water Framework Directive. Common implementation strategy for the Water Framework Directive (2000/60/EC). Guidance document No. 25, Technical Report - 2010-041; Office for Official Publications of the European Communities: Luxembourg, 2010, http://dx.doi.org/10. $2779 / 43586$.

(26) OSPAR Joint Assessment and Monitoring Programme (JAMP) 2014-2021. Update 2015 (Agreement 2014-02) OSPAR Commission, London, 2015. http:/ /www.ospar.org/documents? $\mathrm{d}=32988$.

(27) OSPAR. Co-ordinated Environmental Monitoring Programme Assessment Manual for contaminants in sediment and biota., Publication Number No. 379/2008; OSPAR Commission: London, 2008. http:// www.ospar.org/documents? $\mathrm{d}=7115$.

(28) EU Directive 2008/56/EC of 17 June 2008 establishing a framework for community action in the field of marine environmental policy (Marine Strategy Framework Directive) Off. J. Eur. Un. 2008, L164, 19-40.

(29) OSPAR. OSPAR/ICES Workshop on the Evaluation and Update of Background Reference Concentrations (B/RCs) and Ecotoxicological Assessment Criteria (EACs) and How These Assessment Tools Should Be Used in Assessing Contaminants in Water, Sediment and Biota; OSPAR Commission, London, 2004. http://www.ospar.org/documents?v= 6989.

(30) OSPAR. CEMP Assessment Report: 2008/2009 Assessment of Trends and Concentrations of Selected Hazardous Substances in Sediments and Biota.; OSPAR Commission, London, 2009. http://www.ospar. org/documents? $\mathrm{d}=7196$.

(31) Law, R.; Hanke, G.; Angelidis, M.; Batty, J.; Bignert, A.; Dachs, J.; Davies, I.; Denga, Y.; Duffek, A.; Herut, B.; Hylland, K.; Lepom, P.; Leonards, P.; Mehtonen, J.; Piha, H.; Roose, P.; Tronczynski, J.; Velikova, V.; Vethaak, D. Marine Strategy Framework Directive. Task Group 8 Report. Contaminants and Pollution Effects., EUR 24335 EN 2010; Office for Official Publications of the European Communities: Luxembourg, 2010. http://dx.doi.org/10.2788/85887.

(32) U.S. EPA. Strategy for Water Quality Standards and Criteria. Setting Priorities to Strengthen the Foundation for Protecting and Restoring the Nation's Waters., EPA-823-R-03-010; US-EPA, Office of Science and Technology, 2003. http://www.epa.gov/sites/production/files/201501/documents/strategy-final-2003.pdf.

(33) U.S. Government. 40 CFR 136, updated 1 July 2013. Guidelines Establishing Test Procedures for the Analysis of Pollutants, 2013. http:// www.gpo.gov/fdsys/pkg/CFR-2013-title40-vol24/pdf/CFR-2013title40-vol24-part136.pdf.

(34) U.S. EPA. Consolidated Assessment and Listing Methodology. Toward a Compendium of Best Practices, 2002. http://www.epa.gov/ sites/production/files/2015-09/documents/consolidated_ assessment_and_listing_methodology_calm.pdf.

(35) Smèdes, F.; Booij, K. Guidelines for Passive Sampling of Hydrophobic Contaminants in Water Using Silicone Rubber Samplers.; ICES Techniques in Marine Environmental Sciences No. 52.; 2012. http: / / www.ices.dk/sites/pub/Publication\%20Reports / Techniques\%20in\%20Marine\%20Environmental\%20Sciences\%20( TIMES)/times52/120621\%20TIMES\%2052\%20Final.pdf.

(36) Huckins, J. N.; Petty, J. D.; Prest, H. F.; Clark, R. C.; Alvarez, D. A.; Orazio, C. E.; Lebo, J. A.; Cranor, W. L.; Johnson, B. T. A Guide for the Use of Semipermeable Membrane Devices (SPMDs) As Samplers of
Waterborne Hydrophobic Organic Contaminants., PI publication 4690; American Petroleum Institute, Washington, DC, 2002.

(37) Alvarez, D. A. Guidelines for the Use of the Semipermeable Membrane Device (SPMD) and the Polar Organic Chemical Integrative Sampler (POCIS) in Environmental Monitoring Studies, Techniques and Methods 1-D4; U.S. Geological Survey: Reston, Virginia, 2010. http:// pubs.usgs.gov/tm/tm1d4/pdf/tm1d4.pdf.

(38) ASTM International. Standard Test Method for Determination of Parent and Alkyl Polycyclic Aromatics in Sediment Pore Water Using SolidPhase Microextraction and Gas Chromatography/Mass Spectrometry in Selected Ion Monitoring Mode; ASTM D7363-13a; ASTM International: West Conshohocken, PA, 2013.

(39) Ricci, M.; Kourtchev, I.; Emons, H. Chemical water monitoring under the Water Framework Directive with Certified Reference Materials. TrAC, Trends Anal. Chem. 2012, 36, 47-57.

(40) U.S. EPA. Guidelines for Deriving Numerical National Water Quality Criteria for the Protection of Aquatic Organisms and Their Uses., PB85-227049; Office of Research and Development, Environmental Research Laboratories, Duluth MN, Narragansett RI, Corvallis OR, 1985. http://www.epa.gov/sites/production/files/2015-08/ documents/guidelines_for_deriving_nnwqc_for_the_protectin_of_ aquatic_organisms_and_their_uses.pdf.

(41) U.S. EPA. Methodology for Deriving Ambient Water Quality Criteria for the Protection of Human Health (2000)., EPA-822-B-00-004; U.S. EPA, Office of Science and Technology, Office of Water, Washington, DC 20460, 2000. http://www.epa.gov/nscep.

(42) U.S. EPA. Methodology for Deriving Ambient Water Quality Criteria for the Protection of Human Health (2000). Technical Support Document Vol. 2: Development of National Bioaccumulation Factors., EPA-822-R-03030; Office of Water, Office of Science and Technology: Washington, DC, 2003. http://www.epa.gov/nscep.

(43) U.S. EPA. Methodology for Deriving Ambient Water Quality Criteria for the Protection of Human Health (2000). Technical Support Document Vol. 3: Development of Site-Specific Bioaccumulation Factors, EPA-822-R09-008; Office of Water, Office of Science and Technology, 2009. http://www.epa.gov/nscep.

(44) Lepper, P. Towards the derivation of quality standards for priority substances in the context of the Water Framework Directive; FraunhoferInstitute Molecular Biology and Applied Ecology: SchmallenbergGrafschaft, 2002.

(45) EU. Common Implementation Strategy for the Water Framework Directive. Environmental Quality Standards (EQS) substance data sheet priority substance No. 16, hexachlorobenzene; 2005. https://circabc. europa.eu/sd/a/b2ba7a2c-6a6c-497a-9568-08b4d01c35e8/16_ HxChlBenzene_EQSdatasheet_150105.pdf.

(46) ISO. Guidance on Passive Sampling in Surface Waters,ISO 566723:2011(E); International Organization for Standardization: Geneva, 2011.

(47) Ghosh, U.; Driscoll, S. K.; Burgess, R. M.; Jonker, M. T. O.; Reible, D.; Gobas, F.; Choi, Y. J.; Apitz, S. E.; Maruya, K. A.; Gala, W. R.; Mortimer, M.; Beegan, C. Passive sampling methods for contaminated sediments: Practical guidance for selection, calibration, and implementation. Integr. Environ. Assess. Manage. 2014, 10, 210-223.

(48) OSPAR. JAMP Guidelines for Monitoring of Contaminants in Seawater; Agreement 2013-03; 2013. http://www.ospar.org/ documents? $\mathrm{d}=32946$.

(49) Allan, I. J.; Booij, K.; Paschke, A.; Vrana, B.; Mills, G. A.; Greenwood, R. Field performance of seven passive sampling devices for monitoring of hydrophobic substances. Environ. Sci. Technol. 2009, 43, 5383-5390.

(50) Smedes, F. NORMAN Interlaboratory study (ILS) on passive sampling of emerging pollutants. Study results: BDEs; Dissemination Workshop on Norman ILS on Passive Sampling, Ispra, Italy, 29-30 October. http://www.norman-network.com/sites/default/files/files/ Events/2012/20120 ct29-30 - Is pra -

NormanInterLabStudyOnPassiveSampling/11_foppe_smedes_ norman_ils_study_bde.pdf.

(51) Miege, C.; Mazzella, N.; Schiavone, S.; Dabrin, A.; Berho, C.; Ghestem, J. P.; Gonzalez, C.; Gonzalez, J. L.; Lalere, B.; Lardy-Fontan, 
S.; Lepot, B.; Munaron, D.; Tixier, C.; Togola, A.; Coquery, M. An in situ intercomparison exercise on passive samplers for monitoring metals, polycyclic aromatic hydrocarbons and pesticides in surface waters. TrAC, Trends Anal. Chem. 2012, 36, 128-143.

(52) Booij, K.; Smedes, F. An improved method for estimating in situ sampling rates of nonpolar passive samplers. Environ. Sci. Technol. 2010, 44, 6789-6794.

(53) MCWG. Report of the Marine Chemistry Working Group (MCWG).; ICES: Copenhagen, 2013. http://www.ices.dk/sites/pub/ Publication\%20Reports/Expert\%20Group\%20Report/SSGHIE/2013/ MCWG13.pdf.

(54) Mills, G. A.; Fones, G. R.; Booij, K.; Greenwood, R. Passive sampling technologies. In Chemical Marine Monitoring. Policy Framework and Analytical Trends; Quevauviller, P., Roose, P., Verreet, G., Eds.; John Wiley and Sons: Chichester, 2011; pp 397-432.

(55) Harman, C.; Grung, M.; Djedjibegovic, J.; Marjanovic, A.; Sober, M.; Sinanovic, K.; Fjeld, E.; Rognerud, S.; Ranneklev, S. B.; Larssen, T. Screening for Stockholm Convention persistent organic pollutants in the Bosna River (Bosnia and Herzogovina). Environ. Monit. Assess. 2013, 185, 1671-1683.

(56) Sacks, V. P.; Lohmann, R. Freely dissolved PBDEs in water and porewater of an urban estuary. Environ. Pollut. 2012, 162, 287-293.

(57) Perron, M. M.; Burgess, R. M.; Suuberg, E. M.; Cantwell, M. G.; Pennell, K. G. Performance of passive samplers for monitoring estuarine water column concentrations: 2. Emerging contaminants. Environ. Toxicol. Chem. 2013, 32, 2190-2196.

(58) Allan, I. J.; Harman, C.; Ranneklev, S. B.; Thomas, K. V.; Grung, M. Passive sampling for target and nontarget analyses of moderately polar and nonpolar substances in water. Environ. Toxicol. Chem. 2013, 32, 1718-1726.

(59) Sacks, V. P.; Lohmann, R. Development and use of polyethylene passive samplers to detect triclosans and alkylphenols in an urban estuary. Environ. Sci. Technol. 2011, 45, 2270-2277.

(60) Alvarez, D. A.; Maruya, K. A.; Dodder, N. G.; Lao, W. J.; Furlong, E. T.; Smalling, K. L. Occurrence of contaminants of emerging concern along the California coast (2009-10) using passive sampling devices. Mar. Pollut. Bull. 2014, 81, 347-354.

(61) Moschet, C.; Vermeirssen, E. L. M.; Seiz, R.; Pfefferli, H.; Hollender, J. Picogram per liter detections of pyrethroids and organophosphates in surface waters using passive sampling. Water Res. 2014, 66, 411-422.

(62) Tucca, F.; Moya, H.; Barra, R. Ethylene vinyl acetate polymer as a tool for passive sampling monitoring of hydrophobic chemicals in the salmon farm industry. Mar. Pollut. Bull. 2014, 88, 174-179.

(63) Bruemmer, J.; Falcon, R.; Greenwood, R.; Mills, G. A.; Hastie, C.; Sparham, C.; van Egmond, R. Measurement of cyclic volatile methylsiloxanes in the aquatic environment using low-density polyethylene passive sampling devices using an in-field calibration study Challenges and guidance. Chemosphere 2015, 122, 38-44.

(64) Mayer, P.; Vaes, W. H. J.; Wijnker, F.; Legierse, K. C. H. M.; Kraaij, R.; Tolls, J.; Hermens, J. L. M. Sensing dissolved sediment pore water concentrations of persistent and bioaccumulative pollutants using disposable solid-phase microextraction fibers. Environ. Sci. Technol. 2000, 34, 5177-5183.

(65) Mayer, P.; Karlson, U.; Christensen, P. S.; Johnsen, A. R.; Trapp, $S$. Quantifying the effect of medium composition on the diffusive mass transfer of hydrophobic organic chemicals through unstirred boundary layers. Environ. Sci. Technol. 2005, 39, 6123-6129.

(66) Smedes, F.; van Vliet, L. A.; Booij, K. Multi-ratio equilibrium passive sampling method to estimate accessible and pore water concentrations of polycyclic aromatic hydrocarbons and polychlorinated biphenyls in sediment. Environ. Sci. Technol. 2013, 47, 510-517.

(67) Jahnke, A.; Mayer, P.; Broman, D.; McLachlan, M. S. Possibilities and limitations of equilibrium sampling using polydimethylsiloxane in fish tissue. Chemosphere 2009, 77, 764-770.

(68) Allan, I. J.; Baek, K.; Haugen, T. O.; Hawley, K. L.; Hogfeldt, A. S.; Lillicrap, A. D. In vivo passive sampling of nonpolar contaminants in brown trout (Salmo trutta). Environ. Sci. Technol. 2013, 47, 1166011667.
(69) Booij, K.; Vrana, B.; Huckins, J. N. Theory, modelling and calibration of passive samplers used in water monitoring. In Passive Sampling Techniques in Environmental Monitoring; Greenwood, R., Mills, G. A., Vrana, B., Eds.; Elsevier: Amsterdam, 2007; pp 141-169.

(70) Vrana, B.; Smedes, F.; Rusina, T. P.; Okonski, K.; Allan, I. J.; Grung, M.; Hilscherova, K.; Novák, J.; Tarábek, P.; Slobodník, J. Passive sampling: chemical analysis and toxicological profiling. In Joint Danube Survey 3. A Comprehensive Analysis of Danube Water Quality; Liška, I., Wagner, F., Sengl, M., Deutsch, K., Slobodnik, J., Eds.; International Commission for the Protection of the Danube River: Vienna, Austria, 2015; pp 304-315.

(71) Allan, I. J.; Nilsson, H. C.; Tjensvoll, I.; Bradshaw, C.; Naes, K. Mobile passive samplers: Concept for a novel mode of exposure. Environ. Pollut. 2011, 159, 2393-2397.

(72) Vrana, B.; Mills, G.; Greenwood, R.; Knutsson, J.; Svensson, K.; Morrison, G. Performance optimization of a passive sampler for monitoring hydrophobic organic pollutants in water. J. Environ. Monit. 2005, 7, 612-620.

(73) Vaes, W. H. J.; Hamwijk, C.; Ramos, E. U.; Verhaar, H. J. M.; Hermens, J. L. M. Partitioning of organic chemicals to polyacrylatecoated solid phase microextraction fibers: Kinetic behavior and quantitative structure-property relationships. Anal. Chem. 1996, 68, $4458-4462$.

(74) ter Laak, T. L.; Busser, F. J. M.; Hermens, J. L. M. Poly(dimethylsiloxane) as passive sampler material for hydrophobic chemicals: Effect of chemical properties and sampler characteristics on partitioning and equilibration times. Anal. Chem. 2008, 80, 3859-3866.

(75) Booij, K.; Hofmans, H. E.; Fischer, C. V.; van Weerlee, E. M. Temperature-dependent uptake rates of non-polar organic compounds by semipermeable membrane devices and low-density polyethylene membranes. Environ. Sci. Technol. 2003, 37, 361-366.

(76) Lohmann, R. Critical review of low-density polyethylene's partitioning and diffusion coefficients for trace organic contaminants and implications for its use as a passive sampler. Environ. Sci. Technol. 2012, 46, 606-618.

(77) Rusina, T. P.; Smedes, F.; Klanova, J.; Booij, K.; Holoubek, I. Polymer selection for passive sampling: A comparison of critical properties. Chemosphere 2007, 68, 1344-1351.

(78) Rusina, T. P.; Smedes, F.; Koblizkova, M.; Klanova, J. Calibration of silicone rubber passive samplers: experimental and modeled relations between sampling rate and compound properties. Environ. Sci. Technol. 2010, 44, 362-367.

(79) Hong, L.; Luthy, R. G. Uptake of PAHs into polyoxymethylene and application to oil-soot (lampblack)-impacted soil samples. Chemosphere 2008, 72, 272-281.

(80) Crank, J. The Mathematics of Diffusion; University Press: Oxford, 1975.

(81) Allan, I. J.; Booij, K.; Paschke, A.; Vrana, B.; Mills, G. A.; Greenwood, R. Short-term exposure testing of six different passive samplers for the monitoring of hydrophobic contaminants in water. J. Environ. Monit. 2010, 12, 696-703.

(82) Rusina, T. P.; Smedes, F.; Klanova, J. Diffusion coefficients of polychlorinated biphenyls and polycyclic aromatic hydrocarbons in polydimethylsiloxane and low-density polyethylene polymers. J. Appl. Polym. Sci. 2010, 116, 1803-1810.

(83) Ahn, S.; Werner, D.; Karapanagioti, H. K.; McGlothlin, D. R.; Zare, R. N.; Luthy, R. G. Phenanthrene and pyrene sorption and intraparticle diffusion in polyoxymethylene, coke, and activated carbon. Environ. Sci. Technol. 2005, 39, 6516-6526.

(84) Levich, V. G. Physicochemical Hydrodynamics; Prentice Hall, Inc.: Englewood Cliffs, NJ, 1962.

(85) Hanratty, T. J.; Campbell, J. A. Measurement of wall shear stress. In Fluid Mechanics Measurements; Goldstein, R. J., Ed.; Hemisphere Publishing Corporation: New York, 1983; pp 559-205.

(86) Booij, K.; Smedes, F.; Vrana, B. Uncertainties in passive sampling of nonpolar contaminants. http://www.norman-network.net/sites/ default/files/_thumbs/Files/Events/2013/2013Jul34PassiveSampling-EQS/1140_Brno_EQS_uncertainty_presentation_ v3_KeesBooij.pdf. 
(87) Vrana, B.; Mills, G. A.; Kotterman, M.; Leonards, P.; Booij, K.; Greenwood, R. Modelling and field application of the Chemcatcher passive sampler calibration data for the monitoring of hydrophobic organic pollutants in water. Environ. Pollut. 2007, 145, 895-904.

(88) Prokes, R.; Vrana, B.; Klanova, J.; Kupec, J. Calibration of three passive samplers of hydrophobic organic compounds in water: assessment of critical issues in experimental design, data interpretation and field application. Fresen. Environ. Bull. 2010, 19, 2812-2822.

(89) Anderson, K. A.; Sethajintanin, D.; Sower, G.; Quarles, L. Field trial and modeling of uptake rates of in situ lipid-free polyethylene membrane passive sampler. Environ. Sci. Technol. 2008, 42, 4486-4493.

(90) Lohmann, R.; Booij, K.; Smedes, F.; Vrana, B. Use of passive sampling devices for monitoring and compliance checking of POP concentrations in water. Environ. Sci. Pollut. Res. 2012, 19, 1885-1895. (91) Booij, K.; Hoedemaker, J. R.; Bakker, J. F. Dissolved PCBs, PAHs, and $\mathrm{HCB}$ in pore waters and overlying waters of contaminated harbor sediments. Environ. Sci. Technol. 2003, 37, 4213-4220.

(92) Llorca, J.; Gutierrez, C.; Capilla, E.; Tortajada, R.; Sanjuan, L.; Fuentes, A.; Valor, I. Constantly stirred sorbent and continuous flow integrative sampler. New integrative samplers for the time weighted average water monitoring. J. Chromatogr. A 2009, 1216, 5783-5792.

(93) Chen, Y.; Pawliszyn, J. Kinetics and the on-site application of standards in a solid-phase microextraction fiber. Anal. Chem. 2004, 76, 5807-5815.

(94) Huckins, J. N.; Manuweera, G. K.; Petty, J. D.; Mackay, D.; Lebo, J. A. Lipid-containing semipermeable membrane devices for monitoring organic contaminants in water. Environ. Sci. Technol. 1993, 27, 24892496.

(95) Huckins, J. N.; Petty, J. D.; Lebo, J. A.; Almeida, F. V.; Booij, K.; Alvarez, D. A.; Cranor, W. L.; Clark, R. C.; Mogensen, B. B. Development of the permeability/performance reference compound approach for in situ calibration of semipermeable membrane devices. Environ. Sci. Technol. 2002, 36, 85-91.

(96) Vrana, B.; Mills, G. A.; Dominiak, E.; Greenwood, R. Calibration of the Chemcatcher passive sampler for the monitoring of priority organic pollutants in water. Environ. Pollut. 2006, 142, 333-343.

(97) Perron, M. M.; Burgess, R. M.; Suuberg, E. M.; Cantwell, M. G.; Pennell, K. G. Performance of passive samplers for monitoring estuarine water column concentrations: 1. Contaminants of concern. Environ. Toxicol. Chem. 2013, 32, 2182-2189.

(98) Smedes, F.; Geertsma, R. W.; van der Zande, T.; Booij, K. Polymer-water partition coefficients of hydrophobic compounds for passive sampling: application of cosolvent models for validation. Environ. Sci. Technol. 2009, 43, 7047-7054.

(99) Endo, S.; Hale, S. E.; Goss, K. U.; Arp, H. P. H. Equilibrium partition coefficients of diverse polar and nonpolar organic compounds to polyoxymethylene (POM) passive sampling devices. Environ. Sci. Technol. 2011, 45, 10124-10132.

(100) Liu, H. H.; Wong, C. S.; Zeng, E. Y. Recognizing the limitations of performance reference compound (PRC)-calibration technique in passive water sampling. Environ. Sci. Technol. 2013, 47, 10104-10105.

(101) Harman, C.; Booij, K. Letter to the Editor concerning the viewpoint: "Recognizing the limitations of performance reference compound (PRC)-calibration technique in passive water sampling". Environ. Sci. Technol. 2014, 48, 3.

(102) Wennrich, L.; Vrana, B.; Popp, P.; Lorenz, W. Development of an integrative passive sampler for the monitoring of organic water pollutants. J. Environ. Monit. 2003, 5, 813-822.

(103) Martin, H.; Patterson, B. M.; Davis, G. B. Field trial of contaminant groundwater monitoring: Comparing time-integrating ceramic dosimeters and conventional water sampling. Environ. Sci. Technol. 2003, 37, 1360-1364.

(104) Jonker, M. T. O.; van der Heijden, S. A.; Kotte, M.; Smedes, F. Quantifying the effects of temperature and salinity on partitioning of hydrophobic organic chemicals to silicone rubber passive samplers. Environ. Sci. Technol. 2015, 49, 6791-6799.

(105) Booij, K.; van Bommel, R.; van Aken, H. M.; van Haren, H.; Brummer, G. J. A.; Ridderinkhof, H. Passive sampling of nonpolar contaminants at three deep-ocean sites. Environ. Pollut. 2014, 195, 101108.

(106) Difilippo, E. L.; Eganhouse, R. P. Assessment of PDMS-water partition coefficients: implications for passive environmental sampling of hydrophobic organic compounds. Environ. Sci. Technol. 2010, 44, 6917-6925.

(107) Mayer, P.; Tolls, J.; Hermens, J. L. M.; Mackay, D. Equilibrium sampling devices. Environ. Sci. Technol. 2003, 37, 184A-191A.

(108) Jahnke, A.; Mayer, P.; Adolfsson-Erici, M.; McLachlan, M. S. Equilibrium sampling of environmental pollutants in fish: comparison with lipid-normalized concentrations and homogenization effects on chemical activity. Environ. Toxicol. Chem. 2011, 30, 1515-1521.

(109) Jahnke, A.; Mayer, P.; McLachlan, M. S. Sensitive equilibrium sampling to study polychlorinated biphenyl disposition in Baltic Sea sediment. Environ. Sci. Technol. 2012, 46, 10114-10122.

(110) Jacquet, R.; Miege, C.; Smedes, F.; Tixier, C.; Tronczynski, J.; Togola, A.; Berho, C.; Valor, I.; Llorca, J.; Barillon, B.; Marchand, P.; Coquery, $\mathrm{M}$. Comparison of five integrative samplers in laboratory for the monitoring of indicator and dioxin-like polychlorinated biphenyls in water. Chemosphere 2014, 98, 18-27.

(111) Cornelissen, G.; Broman, D.; Naes, K. Freely dissolved PCDD/F concentrations in the Frierfjord, Norway: comparing equilibrium passive sampling with "active" water sampling. J. Soils Sediments 2010, $10,162-171$.

(112) Fernandez, L. A.; Lao, W.; Maruya, K. A.; White, C.; Burgess, R. M. Passive sampling to measure baseline dissolved persistent organic pollutant concentrations in the water column of the Palos Verdes shelf superfund site. Environ. Sci. Technol. 2012, 46, 11937-11947.

(113) Smedes, F.; van der Zande, A.; Tixier, C.; Davies, I. M. ICES passive sampling trial survey for water and sediment (PSTS) 20062007. Part 2: laboratory intercomparison, analytical issues and lessons learned. ICES Annual Science Conference, Helsinki, 17-21 September. www.ices.dk/sites/pub/CM\%20Doccuments/CM-2007/J/J0307.pdf.

(114) Van Leeuwen, S. P. J.; van Bavel, B.; de Boer, J. First worldwide UNEP interlaboratory study on persistent organic pollutants (POPs), with data on polychlorinated biphenyls and organochlorine pesticides. TrAC, Trends Anal. Chem. 2013, 46, 110-117.

(115) de Boer, J.; Wells, D. E. Chlorobiphenyls and organochlorine pesticides in fish and sediments - Three years of QUASIMEME laboratory performance studies. Mar. Pollut. Bull. 1997, 35, 52-63.

(116) Law, R. J.; Kelly, C. A.; Nicholson, M. D. The QUASIMEME laboratory performance study of polycyclic aromatic hydrocarbons (PAHs): Assessment for the period 1996-1999. J. Environ. Monit. 2000, 2, 517-523.

(117) Allan, I. J.; Harman, C.; Kringstad, A.; Bratsberg, E. Effect of sampler material on the uptake of PAHs into passive sampling devices. Chemosphere 2010, 79, 470-475.

(118) Hermans, J. H.; Smedes, F.; Hofstraat, J. W.; Cofino, W. P. A method for estimation of chlorinated biphenyls in surface waters: influence of sampling method on analytical results. Environ. Sci. Technol. 1992, 26, 2028-2034.

(119) Ellis, S. G.; Booij, K.; Kaputa, M. Comparison of semipermeable membrane device (SPMD) and large-volume solid-phase extraction techniques to measure water concentrations of $4,4^{\prime}-\mathrm{DDT}, 4,4^{\prime}-\mathrm{DDE}$, and 4,4'-DDD in Lake Chelan, Washington. Chemosphere 2008, 72, $1112-1117$

(120) Røe Utvik, T. I.; Durell, G. S.; Johnsen, S. Determining produced water originating polycyclic aromatic hydrocarbons in North Sea waters: comparison of sampling techniques. Mar. Pollut. Bull. 1999, 38, 977989.

(121) Prokes, R.; Vrana, B.; Klanova, J. Levels and distribution of dissolved hydrophobic organic contaminants in the Morava river in Zlin district, Czech Republic as derived from their accumulation in silicone rubber passive samplers. Environ. Pollut. 2012, 166, 157-166.

(122) Tang, J. F.; Chen, S.; Xu, Y. P.; Zhong, W. J.; Ma, M.; Wang, Z. J. Calibration and field performance of triolein embedded acetate membranes for passive sampling persistent organic pollutants in water. Environ. Pollut. 2012, 164, 158-163. 
(123) Reitsma, P. J.; Adelman, D.; Lohmann, R. Challenges of using polyethylene passive samplers to determine dissolved concentrations of parent and alkylated PAHs under cold and saline conditions. Environ. Sci. Technol. 2013, 47, 10429-10437.

(124) Emelogu, E. S.; Pollard, P.; Robinson, C. D.; Webster, L.; McKenzie, C.; Napier, F.; Steven, L.; Moffat, C. F. Identification of selected organic contaminants in streams associated with agricultural activities and comparison between autosampling and silicone rubber passive sampling. Sci. Total Environ. 2013, 445-446, 261-272.

(125) Monteyne, E.; Roose, P.; Janssen, C. R. Application of a silicone rubber passive sampling technique for monitoring PAHs and PCBs at three Belgian coastal harbours. Chemosphere 2013, 91, 390-398.

(126) Allan, I. J.; Nilsson, H. C.; Tjensvoll, I.; Bradshaw, C.; Naes, K. $\mathrm{PCDD} / \mathrm{F}$ release during benthic trawler-induced sediment resuspension. Environ. Toxicol. Chem. 2012, 31, 2780-2787.

(127) Parkerton, T. F.; Maruya, K. A. Passive sampling in contaminated sediment assessment: building consensus to improve decision making. Integr. Environ. Assess. Manage. 2014, 10, 163-166.

(128) Parkerton, T. F., Maruya, K. A., Lydy, M. J., Landrum, P. F., Peijnenburg, W., Mayer, P., Escher, B. I., Ghosh, U., Kane-Driscol, S., Greenberg, M., Chapman, P. F. Guidance on passive sampling methods to improve management of contaminated sediments. Summary of a SETAC Technical Workshop. Pensacolo FL, USA. http://www.setac. org/default.asp?page=SETACWorkshopSum.

(129) Lydy, M. J.; Landrum, P. F.; Oen, A. M. P.; Allinson, M.; Smedes, F.; Harwood, A. D.; Li, H. Z.; Maruya, K. A.; Liu, J. F. Passive sampling methods for contaminated sediments: state of the science for organic contaminants. Integr. Environ. Assess. Manage. 2014, 10, 167-178.

(130) Mayer, P.; Parkerton, T. F.; Adams, R. G.; Cargill, J. G.; Gan, J.; Gouin, T.; Gschwend, P. M.; Hawthorne, S. B.; Helm, P.; Witt, G.; You, J.; Escher, B. I. Passive sampling methods for contaminated sediments: Scientific rationale supporting use of freely dissolved concentrations. Integr. Environ. Assess. Manage. 2014, 10, 197-209.

(131) Greenberg, M. S.; Chapman, M. S.; Allan, I. J.; Anderson, K. A.; Apitz, S. E.; Beegan, C.; Bridges, T. S.; Brown, S. S.; Cargill, J. G., IV; McCulloch, M. C.; Menzie, C. A.; Shine, J. P.; Parkerton, T. F. Passive sampling methods for contaminated sediments: Risk assessment and management. Integr. Environ. Assess. Manage. 2014, 10, 224-236.

(132) Di Toro, D. M.; Zarba, C. S.; Hansen, D. J.; Berry, W. J.; Swartz, R. C.; Cowan, C. E.; Pavlou, S. P.; Allen, H. E.; Thomas, N. A.; Paquin, P. R. Technical basis for establishing sediment quality criteria for nonionic organic chemicals using equilibrium partitioning. Environ. Toxicol. Chem. 1991, 10, 1541-1583.

(133) McDonough, K. M.; Azzolina, N. A.; Hawthorne, S. B.; Nakles, D. V.; Neuhauser, E. F. An evaluation of the ability of chemical measurements to predict polycyclic aromatic hydrocarbon-contaminated sediment toxicity to Hyalella azteca. Environ. Toxicol. Chem. 2010, 29, 1545-1550.

(134) Jonker, M. T. O.; Koelmans, A. A. Polyoxymethylene solid phase extraction as a partitioning method for hydrophobic organic chemicals in sediment and soot. Environ. Sci. Technol. 2001, 35, 3742-3748.

(135) Fernandez, L. A.; Macfarlane, J. K.; Tcaciuc, A. P.; Gschwend, P. $\mathrm{M}$. Measurement of freely dissolved PAH concentrations in sediment beds using passive sampling with low-density polyethylene strips. Environ. Sci. Technol. 2009, 43, 1430-1436.

(136) Fernandez, L. A.; Harvey, C. F.; Gschwend, P. M. Using performance reference compounds in polyethylene passive samplers to deduce sediment porewater concentrations for numerous target chemicals. Environ. Sci. Technol. 2009, 43, 8888-8894.

(137) Apell, J. N.; Gschwend, P. M. Validating the use of performance reference compounds in passive samplers to assess porewater concentrations in sediment beds. Environ. Sci. Technol. 2014, 48, 10301-10307.

(138) Maenpaa, K.; Leppanen, M. T.; Reichenberg, F.; Figueiredo, K.; Mayer, P. Equilibrium sampling of persistent and bioaccumulative compounds in soil and sediment: comparison of two approaches to determine equilibrium partitioning concentrations in lipids. Environ. Sci. Technol. 2011, 45, 1041-1047.
(139) Cui, X. Y.; Mayer, P.; Gan, J. Methods to assess bioavailability of hydrophobic organic contaminants: Principles, operations, and limitations. Environ. Pollut. 2013, 172, 223-234.

(140) Reichenberg, F.; Mayer, P. Two complementary sides of bioavailability: Accessibility and chemical activity of organic contaminants in sediments and soils. Environ. Toxicol. Chem. 2006, 25, 12391245.

(141) Cornelissen, G.; van Noort, P. C. M.; Govers, H. A. J. Desorption kinetics of chlorobenzenes, polycyclic aromatic hydrocarbons, and polychlorinated biphenyls: sediment extraction with Tenax® and effects of contact time and solute hydrophobicity. Environ. Toxicol. Chem. 1997, $16,1351-1365$.

(142) ten Hulscher, D. E. M.; Vrind, B. A.; van den Heuvel, H.; van der Velde, L. E.; van Noort, P. C. M.; Beurskens, J. E. M.; Govers, H. A. J. Triphasic desorption of highly resistant chlorobenzenes, polychlorinated biphenyls, and polycyclic aromatic hydrocarbons in field contaminated sediment. Environ. Sci. Technol. 1999, 33, 126-132.

(143) Cornelissen, G.; Rigterink, H.; Vrind, B. A.; ten Hulscher, D. T. E. M.; Fernandy, M. M. A.; van Noort, P. C. M. Two-stage desorption kinetics and in situ partitioning of hexachlorobenzene and dichlorobenzenes in a contaminated sediment. Chemosphere 1997, 35, 24052416.

(144) You, J.; Harwood, A. D.; Li, H. Z.; Lydy, M. J. Chemical techniques for assessing bioavailability of sediment-associated contaminants: SPME versus Tenax extraction. J. Environ. Monit. 2011, 13, 792-800.

(145) Harwood, A. D.; Landrum, P. F.; Lydy, M. J. Bioavailabilitybased toxicity endpoints of bifenthrin for Hyalella azteca and Chironomus dilutus. Chemosphere 2013, 90, 1117-1122.

(146) Jonker, M. T. O.; van der Heijden, S. A. Bioconcentration factor hydrophobicity cutoff: an artificial phenomenon reconstructed. Environ. Sci. Technol. 2007, 41, 7363-7369.

(147) Ramos, E. U.; Meijer, S. N.; Vaes, W. H. J.; Verhaar, H. J. M.; Hermens, J. L. M. Using solid-phase microextraction to determine partition coefficients to humic acids and bioavailable concentrations of hydrophobic chemicals. Environ. Sci. Technol. 1998, 32, 3430-3435.

(148) Muijs, B.; Jonker, M. T. O. Temperature-dependent bioaccumulation of polycyclic aromatic hydrocarbons. Environ. Sci. Technol. 2009, 43, 4517-4523.

(149) Kraaij, R.; Mayer, P.; Busser, F. J. M.; Bolscher, M. V.; Seinen, W.; Tolls, J. Measured pore-water concentrations make equilibrium partitioning work - A data analysis. Environ. Sci. Technol. 2003, 37, 268 274.

(150) Leslie, H. A.; ter Laak, T. L.; Busser, F. J. M.; Kraak, M. H. S.; Hermens, J. L. M. Bioconcentration of organic chemicals: Is a solidphase microextraction fiber a good surrogate for biota? Environ. Sci. Technol. 2002, 36, 5399-5404.

(151) Smedes, F. Monitoring of chlorinated biphenyls and polycyclic aromatic hydrocarbons by passive sampling in concert with deployed mussels. In Passive Sampling Techniques in Environmental Monitoring; Greenwood, R., Mills, G. A., Vrana, B., Eds.; Elsevier: Amsterdam, 2007; pp 407-448.

(152) Andrade, N. A.; Centofanti, T.; McConnell, L. L.; Hapeman, C. J.; Torrents, A.; Anh, N.; Beyer, W. N.; Chaney, R. L.; Novak, J. M.; Anderson, M. O.; Cantrell, K. B. Utilizing thin-film solid-phase extraction to assess the effect of organic carbon amendments on the bioavailability of DDT and dieldrin to earthworms. Environ. Pollut. 2014, 185, 307-313.

(153) Meloche, L. M.; deBruyn, A. M. H.; Otton, S. V.; Ikonomou, M. G.; Gobas, F. A. P. C. Assessing exposure of sediment biota to organic contaminants by thin-film solid phase extraction. Environ. Toxicol. Chem. 2009, 28, 247-253.

(154) Golding, C. J.; Gobas, F. A. P. C.; Birch, G. F. A fugacity approach for assessing the bioaccumulation of hydrophobic organic compounds from estuarine sediment. Environ. Toxicol. Chem. 2008, 27, $1047-1054$

(155) Wilcockson, J. B.; Gobas, F. A. P. C. Thin-film solid-phase extraction to measure fugacities of organic chemicals with low volatility in biological samples. Environ. Sci. Technol. 2001, 35, 1425-1431. 
(156) Friedman, C. L.; Burgess, R. M.; Perron, M. M.; Cantwell, M. G.; Ho, K. T.; Lohmann, R. Comparing polychaete and polyethylene uptake to assess sediment resuspension effects on PCB bioavailability. Environ. Sci. Technol. 2009, 43, 2865-2870.

(157) Gschwend, P. M.; Macfarlane, J. K.; Reible, D. D.; Lu, X.; Hawthorne, S. B.; Nakles, D. V.; Thompson, T. Comparison of polymeric samplers for accurately assessing $\mathrm{PCBs}$ in pore waters. Environ. Toxicol. Chem. 2011, 30, 1288-1296.

(158) Vinturella, A. E.; Burgess, R. M.; Coull, B. A.; Thompson, K. M.; Shine, J. P. Use of passive samplers to mimic uptake of polycyclic aromatic hydrocarbons by benthic polychaetes. Environ. Sci. Technol. 2004, 38, 1154-1160.

(159) Muijs, B.; Jonker, M. T. O. Does equilibrium passive sampling reflect actual in situ bioaccumulation of PAHs and petroleum hydrocarbon mixtures in aquatic worms? Environ. Sci. Technol. 2012, 46, 937-944.

(160) van der Heijden, S. A.; Jonker, M. T. O. PAH bioavailability in field sediments: comparing different methods for predicting in situ bioaccumulation. Environ. Sci. Technol. 2009, 43, 3757-3763.

(161) You, J.; Landrum, P. E.; Trimble, T. A.; Lydy, M. J. Availability of polychlorinated biphenyls in field-contaminated sediment. Environ. Toxicol. Chem. 2007, 26, 1940-1948.

(162) Gomez-Eyles, J. L.; Jonker, M. T. O.; Hodson, M. E.; Collins, C. D. Passive samplers provide a better prediction of PAH bioaccumulation in earthworms and plant roots than exhaustive, mild solvent, and cyclodextrin extractions. Environ. Sci. Technol. 2012, 46, 962-969.

(163) Jonker, M. T. O.; van der Heijden, S. A.; Kreitinger, J. P.; Hawthorne, S. B. Predicting PAH bioaccumulation and toxicity in earthworms exposed to manufactured gas plant soils with solid-phase microextraction. Environ. Sci. Technol. 2007, 41, 7472-7478.

(164) Lu, X. X.; Skwarski, A.; Drake, B.; Reible, D. D. Predicting bioavailability of PAHs and PCBs with porewater concentrations measured by solid-phase microextraction fibers. Environ. Toxicol. Chem. 2011, 30, 1109-1116.

(165) Thomas, C.; Lampert, D.; Reible, D. Remedy performance monitoring at contaminated sediment sites using profiling solid phase microextraction (SPME) polydimethylsiloxane (PDMS) fibers. Env. Sci. Process. Impact. 2014, 16, 445-452.

(166) Jahnke, A.; McLachlan, M. S.; Mayer, P. Equilibrium sampling: partitioning of organochlorine compounds from lipids into polydimethylsiloxane. Chemosphere 2008, 73, 1575-1581.

(167) Jahnke, A.; MacLeod, M.; Wickstrom, H.; Mayer, P. Equilibrium sampling to determine the thermodynamic potential for bioaccumulation of persistent organic pollutants from sediment. Environ. Sci. Technol. 2014, 48, 11352-11359.

(168) Jahnke, A.; Mayer, P.; McLachlan, M. S.; Wickstrom, H.; Gilbert, D.; MacLeod, M. Silicone passive equilibrium samplers as 'chemometers' in eels and sediments of a Swedish lake. Env. Sci. Process. Impact. 2014, 16, 464-472.

(169) Schäfer, S.; Antoni, C.; Möhlenkamp, C.; Claus, E.; Reifferscheid, G.; Heininger, P.; Mayer, P. Equilibrium sampling of polychlorinated biphenyls in River Elbe sediments - Linking bioaccumulation in fish to sediment contamination. Chemosphere 2015, 138, 856-862.

(170) Arnot, J. A.; Gobas, F. A. P. C. A generic QSAR for assessing the bioaccumulation potential of organic chemicals in aquatic food webs. QSAR Comb. Sci. 2003, 22, 337-345.

(171) Witt, G.; Liehr, G. A.; Borck, D.; Mayer, P. Matrix solid-phase microextraction for measuring freely dissolved concentrations and chemical activities of PAHs in sediment cores from the western Baltic Sea. Chemosphere 2009, 74, 522-529.

(172) Ossiander, L.; Reichenberg, F.; McLachlan, M. S.; Mayer, P. Immersed solid phase microextraction to measure chemical activity of lipophilic organic contaminants in fatty tissue samples. Chemosphere 2008, 71, 1502-1510.

(173) Mayer, P.; Torang, L.; Glaesner, N.; Jonsson, J. A. Silicone membrane equilibrator: measuring chemical activity of nonpolar chemicals with poly(dimethylsiloxane) microtubes immersed directly in tissue and lipids. Anal. Chem. 2009, 81, 1536-1542.
(174) Booij, K.; Smedes, F.; van Weerlee, E. M.; Honkoop, P. J. C. Environmental monitoring of hydrophobic organic contaminants: the case of mussels versus semipermeable membrane devices. Environ. Sci. Technol. 2006, 40, 3893-3900.

(175) Arnot, J. A.; Gobas, F. A. P. C. A review of bioconcentration factor (BCF) and bioaccumulation factor (BAF) assessments for organic chemicals in aquatic organisms. Environ. Rev. 2006, 14, 257-297.

(176) Goldberg, E. D. The Mussel Watch - A first step in global marine monitoring. Mar. Pollut. Bull. 1975, 6, 111.

(177) Lauenstein, G. G. Comparison of organic contaminants found in mussels and oysters from a current mussel watch project with those from archived mollusc samples of the 1970s. Mar. Pollut. Bull. 1995, 30, 826833.

(178) Lauenstein, G. G.; Cantillo, A. Y. Contaminant trends in US National Estuarine Research Reserves., NOAA Technical Memorandum, NOAA NOS NCCOS 156; NOAA, Silver Spring, MD, 2002. http:// aquaticcommons.org/2169/1/NOS TM156.pdf.

(179) Monirith, I.; Ueno, D.; Takahashi, S.; Nakata, H.; Sudaryanto, A.; Subramanian, A.; Karuppiah, S.; Ismail, A.; Muchtar, M.; Zheng, J. S.; Richardson, B. J.; Prudente, M.; Hue, N. D.; Tana, T. S.; Tkalin, A. V.; Tanabe, S. Asia-Pacific mussel watch: monitoring contamination of persistent organochlorine compounds in coastal waters of Asian countries. Mar. Pollut. Bull. 2003, 46, 281-300.

(180) Besse, J. P.; Geffard, O.; Coquery, M. Relevance and applicability of active biomonitoring in continental waters under the Water Framework Directive. TrAC, Trends Anal. Chem. 2012, 36, 113-127.

(181) Vorkamp, K.; Strand, J.; Christensen, J. H.; Svendsen, T. C.; Lassen, P.; Hansen, A. B.; Larsen, M. M.; Andersen, O. Polychlorinated biphenyls, organochlorine pesticides and polycyclic aromatic hydrocarbons in a one-off global survey of bivalves. J. Environ. Monit. 2010, 12, $1141-1152$.

(182) EU. Guidance Document No. 32 on biota monitoring (the implementation of $\left.E Q S_{\text {biota }}\right)$ under the Water Framework Directive. Common Implementation Strategy for the Water Framework Directive (2000/60/EC).; Technical Report - 2014-083; Office for Official Publications of the European Communities: Luxembourg, 2014. http:// dx.doi.org/10.2779/833200. 